NBER WORKING PAPER SERIES

\title{
ELECTED VERSUS APPOINTED REGULATORS: THEORY AND EVIDENCE
}

\author{
Timothy Besley \\ Stephen Coate \\ Working Paper 7579 \\ http://www.nber.org/papers/w7579 \\ NATIONAL BUREAU OF ECONOMIC RESEARCH \\ 1050 Massachusetts Avenue \\ Cambridge, MA 02138 \\ March 2000
}

The authors are grateful to Yun Ho Chung, Tarcisio DaGraca and Imran Rasul for valuable research assistance, to Doug Jones and Dick Schuler for Guidance on the literature and institutions, and to Sharon Tennyson for many useful discussions. We also thank Richard Boylan, Roger Noll and a number of seminar participants for helpful feedback. STICERD provided financial support for the project. The views expressed herein are those of the authors and are not necessarily those of the National Bureau of Economic Research.

(C) 2000 by Timothy Besley and Stephen Coate. All rights reserved. Short sections of text, not to exceed two paragraphs, may be quoted without explicit permission provided that full credit, including $(\subset$ notice, is given to the source. 
Elected versus Appointed Regulators:

Theory and Evidence

Timothy Besley and Stephen Coate

NBER Working Paper No. 7579

March 2000

\begin{abstract}
This paper contrasts direct election with political appointment of regulators. When regulators are appointed, regulatory policy becomes bundled with other policy issues the appointing politicians are responsible for. Since regulatory issues are not salient for most voters, regulatory policy outcomes reflect the preferences of party elites and special interests. Direct election of regulators strengthens the power of voters by ensuring the salience of regulatory issues. Using panel data on regulatory outcomes from U.S. states, we find evidence in favor of the idea that elected states are more pro-consumer in their regulatory policies.
\end{abstract}

Professor Stephen Coate

Department of Economics

Cornell University

476 Uris Hall

Ithaca NY 14853-7601

and NBER

sc163@cornell.edu
Professor Timothy Besley

Department of Economics

London School of Economics

London WC2A 2AE

UNITED KINGDOM

t.besley@1se.ac.uk 


\section{Introduction}

The scope of regulation in modern economies is vast. To this end, the state has devised a variety of institutional structures to handle this task. It is rare for regulatory agencies to be directly accountable to the citizens whom their activities affect. Typically, heads of regulatory agencies are appointed by politicians, creating an insulating layer between citizens and regulators. However, a number of U.S. states have injected a degree of populism into the regulatory process by requiring that the heads of their independent regulatory commissions be directly elected.

How might we expect regulatory policies to differ when regulators are directly elected rather than appointed? While it may seem natural to suppose that direct elections would produce more populist regulators, the theoretical basis for such a belief is far from obvious. Since the appointing politicians are themselves elected, a median voter type analysis would suggest that in either regime the voters should get the type of regulator that the majority of them desire. Consistent with this, existing empirical studies of regulation in the U.S. (e.g. Costello (1984)) have not found convincing evidence of differences in policy outcomes across the U.S. states that elect and appoint their regulators.

This paper revisits this issue. It begins with a theoretical analysis of the difference between electing and appointing regulators. The theory captures the idea that when regulators are appointed, regulatory policy becomes bundled with many other policy issues. Since voters have only one vote to cast and regulatory issues are unlikely to be politically salient, the link between regulatory policy and voters' preferences is likely to be weak. Directly electing regulators, strengthens this link and hence can produce regulators who are more pro-consumer. ${ }^{1}$ This prediction is tested using data on electricity prices from a panel of U.S. states. The results support the idea that direct elections produce more pro-consumer regulators.

The paper contributes to a large literature on the economics of regulation. Theoretical work in this area falls into two main traditions. The normative tradition seeks to provide guidance to regulators as to the type of policies they should employ. In this literature, the term regulation has become largely synonymous with regulation of natural monopolies. Regulators are assumed to care about both consumer and producer surplus, with the relative weight

\footnotetext{
${ }^{1}$ Navarro (1982) pages 126-7 suggests an argument along these lines.
} 
on each being a key parameter. If the regulator can perfectly observe the characteristics of the firms, the social ideal is some kind of marginal cost or Ramsey pricing. However, the more realistic situation is one in which information about costs is imperfect and the literature has focused on the design of schemes that circumvent these information problems (see Laffont and Tirole (1993) for a comprehensive coverage of this literature).

The Chicago tradition, as developed by Stigler (1971) and Peltzman (1976), has tended to take a broader perspective on regulation to include a whole gamut of government activities beyond the concerns of natural monopolies. It has also placed political economy issues at center stage - the main focus being to explain the type of regulations that the political process produces. Regulations are assumed to be chosen by politicians seeking to maximize political "support". The support associated with implementing a particular policy reform depends on the votes and campaign contributions that will be garnered from beneficiaries and withdrawn from losers. In the public utility context, the relative ability of producers and consumers to deliver votes and campaign contributions determines the weight politicians attach to their interests. The logic of concentrated benefits and diffuse costs leads to the general prediction that producers' interests will receive greater consideration in the design of regulatory policies. ${ }^{2}$

The theoretical approach developed in this paper draws on both of these traditions. Our model is consistent with the normative tradition of assuming regulators choose policy to maximize a weighted sum of consumer and producer surplus, but endogenizes the relative weights the regulator uses. ${ }^{3}$ Moreover, it provides a starting point for a normative analysis of alternative methods of regulator selection. This is timely, as there is much debate in the policy literature concerning the design of regulatory institutions and how regulators can be made more accountable (see, for example, Laffont (1996) and Baldwin and Cave (1999)). The model is in the same broad tradition as the Chicago support maximizing models, but is much more explicit about both the political process and the underlying economic environment. The Chicago models leave the idea of "support" vague, with little micro-modelling of elec-

\footnotetext{
${ }^{2}$ See Joskow and Noll (1981) and Baron (1995) for overviews of the literature on the political economy of regulation.

${ }^{3}$ In this respect, it is similar to the work of Baron (1988). He studies a model in which the weight the regulator puts on producer surplus is chosen by a majority rule legislature. In contrast to our analysis, however, the regulatory preferences of the politicians appointing the regulator are assumed to be exogneous.
} 
tions, campaign contributions, etc. While such a reduced form approach has the merit of generality, it is less useful when seeking guidance as to the effect of changing the institutional structure on policy outcomes.

The large empirical literature on the effects of regulation begins with the seminal contribution of Stigler and Friedland (1962) and is expertly reviewed in Joskow and Rose (1989). The cross-state variation between regulatory regimes in the United States has understandably been a rich testing ground for the economic effects of regulation. That institutional variation afforded by rules for appointing commissions provides scope for empirical testing has not escaped the eye of previous researchers. A number of studies including Berry (1979), Costello (1984), Crain and McCormick (1984), Harris and Navarro (1983), Navarro (1982), and Primeaux and Mann (1986), have looked at the evidence from different perspectives and it is to this strand of the empirical literature that the paper contributes. Some of these contributions have looked at rate setting, while others have looked at broader indicators of how favorable is the regulatory climate within a state. Costello (1984)'s review of the evidence concludes that "In summary, it probably makes little difference to the average ratepayer whether a PUC is elected or appointed." (page 104). However, the data and time periods used differ across studies as do the set of controls and institutional measures. More worrisome for convincing empirical testing is the fact that the literature is predominantly cross-sectional with particular researchers choosing selected years and available controls to report their findings. The major concern in this case is that the decision to elect or appoint regulators is simply correlated with important unobservable differences between states. Yet, the U.S. state structure provides a natural vehicle for a panel data analysis where many of these concerns can be mitigated and our empirical analysis exploits this.

The remainder of the paper is organized as follows. The next section presents the theory, explaining why direct elections are more likely to produce pro-consumer regulators than appointed regimes. Section 3 tests this prediction using electricity price data from the U.S. states. Section 4 discusses the significance of this finding and some broader issues, while section 5 concludes. The appendix contains proofs of the main propositions as a well as a detailed description of the data and sources that we use. 


\section{Theory}

\subsection{The Model}

We develop the simplest possible model to illustrate why elected regulators are likely to be more pro-consumer than appointed regulators. To incorporate the idea of policy bundling, there are two issues: public spending and regulation. Policies are selected by policy-makers chosen by the voters in elections. Candidates in these elections are put forward by two policy-motivated parties representing different groups of voters.

\subsubsection{The economic environment}

There are $N$ citizens and three goods; a numeraire good $y$, a regulated good $x$ and a public good $g$. Citizens are endowed with the numeraire which can be used to produce the other goods. The regulated good is produced by a single firm which requires $c(x)$ units of the numeraire to produce $x$ units, where $c(\cdot)$ is increasing and twice continuously differentiable. The public good is produced by a competitive production sector with a linear technology where $q$ units of the numeraire are required to produce one unit of the public good.

Citizens have differing tastes for the public good. There are two preference types indexed by $k \in\{L, R\}$ where $L$ denotes "left wing" and $R$ "right wing". A citizen of preference type $k$ has a utility function $y+u(x)+\phi(g ; k)$ where $u(\cdot)$ and $\phi(\cdot ; k)$ are increasing, twice continuously differentiable and strictly concave. Left-wingers have a higher marginal willingness to pay for public goods in the sense that $\phi_{g}(g ; L)>\phi_{g}(g ; R)$ for all $g \geq 0$. However, $\phi_{g}(0 ; R)>q / N$ so that all citizens desire a positive amount of the public good when it is uniformly financed.

Citizens have different connections to the regulated firm. There are again two types indexed by $t \in\{C, S\}$ where $C$ denotes "consumer" and $S$ denotes "shareholder". Consumers' only connection to the regulated firm is via their purchases of its output. Shareholders also own part of the firm, with each shareholder holding an equal share. ${ }^{4}$

The fraction of citizens of type $(k, t)$ is denoted $\gamma_{t}^{k}$. We let $\gamma^{k}=\gamma_{C}^{k}+\gamma_{S}^{k}$

\footnotetext{
${ }^{4}$ The role of shareholders in the model is to create a group with an interest in higher rents in the regulated industry. In practice, this could equally be organized labor. Indeed, Joskow and Rose (1989) emphasize the importance of labor as a beneficiary of regulations in many contexts.
} 
denote the fraction of the population with public good preference $k$ and $\gamma_{t}=$ $\gamma_{t}^{L}+\gamma_{t}^{R}$ the fraction with connection to the firm $t$. We assume throughout that shareholders are a minority group in the sense that $\gamma_{S}<\min \left\{\gamma^{L}, \gamma^{R}\right\}$.

\subsubsection{Government policies}

The government has two roles: providing the public good and regulating the firm producing good $x$. The public good costs $q$ and government provision is financed by a head tax. Let $b(g, k)=\phi(g ; k)-q g / N$ denote the surplus that a citizen of preference type $k$ enjoys when $g$ units of the public good are provided and $g^{*}(k)$ denote his preferred level of provision. Our assumptions imply that right-wingers prefer less public spending than left-wingers $\left(g^{*}(R)<g^{*}(L)\right)$.

We suppose that the regulator sets a price $p$ and that the firm is required to meet all consumer demand at this price, subject to it not making a loss. ${ }^{5}$ At price $p$, each citizen demands $x(p)$ units of good $x$ where $x(p)$ maximizes $u(x)-p x$. Aggregate demand is $X(p)=N x(p)$ and the regulated firm's profits are $\pi(p)=p X(p)-c(X(p))$. The price $p$ must satisfy $\pi(p) \geq 0 .{ }^{6}$ (We assume that there exists a price $p$ such that $\pi(p)>0$.)

Letting $r(p, t)$ denote the surplus that a citizen of type $t$ gets from the regulated price $p$, then $r(p, C)=u(x(p))-p x(p)$ and $r(p, S)=r(p, C)+$ $\frac{1}{N \gamma_{S}} \pi(p)$. A consumer's payoff is his consumer surplus, while a shareholder's payoff includes his share of the firm's profits. Let $p^{*}(t)$ denote the optimal price from the perspective of a type $t$; i.e., that which maximizes $r(p, t)$ subject to the constraint of non-negative profits. The optimal consumer price is the lowest price at which the regulated firm does not make a loss,

\footnotetext{
${ }^{5}$ In the case of electricity, discussed below, the assumption of a price setting regulator seems a reasonable approximation, although things are more complicated than this in practice. As Joskow (1974) observes "The statutes establishing most regulatory agencies are usually quote vague. Regulatory agencies are normally mandated to insure that rates charged by regulated firms are "reasonable and non-discriminatory" and that service of the "good quality" is maintained." page 296 (emphasis original). In practice rates should be set to allow stockholders a fair rate of return. However, Joskow (1974) notes that "Contrary to the popular view, it does not appear that regulatory agencies have been concerned with regulating returns per se. The primary concern of regulatory commissions has been to keep nominal prices from increasing." page 298 (emphasis original).

${ }^{6}$ We set aside the possibility that the regulator may have imperfect information about the firm's profit function as covered by Laffont and Tirole (1993). While it would be possible to extend the model in this direction, the same basic ideas developed here would still be important features of the choice between appointing and electing.
} 
implying that $p^{*}(C)$ equals average cost at output $X\left(p^{*}(C)\right)$. The optimal shareholder price also takes into account the firm's profits.

There is no general guarantee that the shareholder's optimal price exceeds the consumer's. To ensure a conflict of interest, we assume that

$$
1-\gamma_{S}>\varepsilon\left(p^{*}(C)\right)\left[1-\frac{c^{\prime}\left(X\left(p^{*}(C)\right)\right)}{p^{*}(C)}\right]
$$

where $\varepsilon(p)$ is the price elasticity of demand. Since $p^{*}(C)=\frac{c\left(X\left(p^{*}(C)\right)\right)}{X\left(p^{*}(C)\right)}$, this condition is satisfied if the monopoly's average costs are increasing at output level $X\left(p^{*}(C)\right)$. If its average costs are decreasing at $X\left(p^{*}(C)\right)$ the condition requires either that demand be relatively inelastic or that the fraction of shareholders in the population is small. Under this assumption, the optimal shareholder price exceeds $p^{*}(C)$ and satisfies the equation

$$
p^{*}(S)=\frac{c^{\prime}\left(X\left(p^{*}(S)\right)\right)}{\left[1-\frac{1-\gamma_{S}}{\varepsilon\left(p^{*}(S)\right)}\right]} .
$$

Finally, we assume that public spending is more important to consumers than regulation in the following sense: For each type of citizen $(k, t)$, the gain from achieving their preferred level of the public good, given by $\Delta b(k)=$ $b\left(g^{*}(k), k\right)-b\left(g^{*}(-k), k\right)$, exceeds the gain from achieving their preferred regulatory price, given by $\Delta r(t)=r\left(p^{*}(t), t\right)-r\left(p^{*}(-t), t\right) .{ }^{7}$ Thus, disagreement over public spending is sharper than that over regulatory policy. This assumption plays a key role in the analysis to follow.

\subsubsection{Policy determination}

We compare two methods of regulator selection: appointment and election. If the regulator is appointed, the community elects a governor whose role is to choose $g$ and appoint a regulator to set $p$. If the regulator is elected, the community elects a governor whose sole task is to choose $g$ and elects a regulator who chooses $p$. In both policy situations, the policy makers are citizens.

Candidates in gubernatorial and regulator elections are selected by two political parties, denoted $A$ and $B$. Each party is comprised of member

\footnotetext{
${ }^{7}$ The notation $-k$ and $-t$ refers to the opposite types to $k$ and $t$. For example, $-k=R$ when $k=L$.
} 
citizens bound together by their views about public spending. Thus, all members of Party $A$ are left-wingers and all members of Party $B$ are rightwingers. Both parties contain a mixture of shareholders and consumers, with $\lambda_{J}$ denoting the fraction of members of Party $J$ who are shareholders.

Parties maximize the average payoff of its members. Thus, Party A's objective function is

$$
W_{A}(g, p)=b(g, L)+\left[r(p, C)+\frac{\lambda_{A}}{N \gamma_{S}} \pi(p)\right]
$$

and that of Party $B$ is

$$
W_{B}(g, p)=b(g, R)+\left[r(p, C)+\frac{\lambda_{B}}{N \gamma_{S}} \pi(p)\right] .
$$

We assume that the fractions of shareholders in the two parties satisfy the following assumption:

Assumption 1: $\frac{\lambda_{A}}{N \gamma_{S}} \pi\left(p^{*}(S)\right)<\Delta r(C)<\frac{\lambda_{B}}{N \gamma_{S}} \pi\left(p^{*}(S)\right)$.

These inequalities imply that Party $A$ prefers a consumer regulator, while Party $B$ prefers a shareholder. ${ }^{8}$

If the regulator is appointed, each party selects a candidate for the gubernatorial race. Since candidates are citizens, they are characterized by their types $(k, t)$. No ex-ante policy commitments are possible, so that, when in office, a type $(k, t)$ candidate chooses a public good level $g^{*}(k)$ and appoints a regulator who shares his type $t$. This regulator then selects a price $p^{*}(t)$.

If the regulator is elected, each party selects two candidates: one for the gubernatorial race and one for the regulator race. While candidates are still characterized by their types $(k, t)$, only one dimension of their type is relevant for their policy-making roles. Thus, if elected governor, a type $(k, t)$ candidate chooses a public good level $g^{*}(k)$ and, if elected regulator, a type $(k, t)$ candidate chooses a price $p^{*}(t)$.

There are two types of voters. ${ }^{9}$ A fraction $\mu$ are rational voters who anticipate the policy outcomes each candidate would deliver and vote for the candidate whose election would produce their highest policy payoff. Thus, if

\footnotetext{
${ }^{8}$ The argument would work equally well under the assumption that Party $A$ preferred a shareholder and Party $B$ a consumer.

${ }^{9}$ This kind of approach is common in the literature following Baron (1994) and Grossman and Helpman (1996).
} 
the regulator is appointed, a rational voter of type $(k, t)$ who is faced with gubernatorial candidates of types $\left(k_{A}, t_{A}\right)$ and $\left(k_{B}, t_{B}\right)$ will vote for Party $A^{\prime}$ 's candidate if $b\left(g^{*}\left(k_{A}\right), k\right)+r\left(p^{*}\left(t_{A}\right), t\right)$ exceeds $b\left(g^{*}\left(k_{B}\right), k\right)+r\left(p^{*}\left(t_{B}\right), t\right)$. Rational voters indifferent between two candidates abstain.

The remaining fraction of voters are noise voters. In each election, a fraction $\eta$ of these vote for Party $A$ 's candidate. Here, $\eta$ is the realization of a random variable with support $[0,1]$ and cumulative distribution function $H(\eta)$. If the regulator is elected, there is a separate (uncorrelated) draw of $\eta$ for each election. The idea is that noise voters respond to non-policy relevant features of candidates such as their looks, sense of humor, etc. We assume that $H$ is symmetric so that for all $\eta, H(\eta)=1-H(1-\eta)$. This implies that noise voters are unbiased in the sense that the probability that a fraction less than $\eta$ vote for Party $A$ 's candidate equals the probability that a fraction less than $\eta$ vote for Party $B$ 's candidate.

Noise voters make the election outcomes probabilistic. To illustrate, consider an election in which the difference between the fraction of citizens obtaining a higher utility from the policy choices generated by Party $A$ 's candidate and the fraction obtaining a higher utility from Party $B$ 's candidate is $\omega$. Since $\mu$ is the fraction of rational voters and $\eta$ the fraction of noise voters who vote for Party $A$ 's candidate, Party $A$ 's candidate will win if $\mu \omega+(1-\mu) \eta>(1-\mu)(1-\eta)$ or, equivalently, if $\eta>\frac{-\mu \omega}{2(1-\mu)}+\frac{1}{2}$. The probability that Party $A$ 's candidate will win is thus $\psi(\omega)$ where $\psi(\omega)=0$ if $\omega \leq \frac{-(1-\mu)}{\mu}, \psi(\omega)=1$ if $\omega \geq \frac{1-\mu}{\mu}$, and $\psi(\omega)=1-H\left(\frac{-\mu \omega}{2(1-\mu)}+\frac{1}{2}\right)$ otherwise.

Parties are assumed to correctly calculate the election probabilities associated with different candidate pairs and take them into account when choosing candidates. We assume that the fraction of noise voters in the population is sufficiently high so that $\left|\gamma^{L}-\gamma^{R}\right|<\frac{1-\mu}{\mu}$. This assumption implies that $\psi\left(\gamma^{L}-\gamma^{R}\right) \in(0,1)$ implying that in an election between a left-winger and a right-winger in which public spending were the only issue, both candidates would win with positive probability.

Any election gives rise to a game between the two parties. Each party's strategy is the type of candidate it selects and its strategy set is the set of possible citizen types. ${ }^{10}$ Each party's payoff from any strategy pair is determined by the probability its candidate wins and its objective function.

\footnotetext{
${ }^{10}$ We do not require that a party must select a candidate from the ranks of its members. However, under the assumptions on preferences we make, parties have no incentive to select from outside their membership in equilibrium.
} 
An equilibrium of the game is a pair of candidate choices, one for each party, that are mutual best responses. Any equilibrium pair of candidates gives rise to a probability distribution over outcomes: the policy outcome will be that associated with Party J's candidate with a probability equal to the chance that Party J's candidate wins.

\subsection{Analysis}

Viewed ex ante, each policy regime generates probability distributions over candidate types and hence policy outcomes. Our interest here is in the type of regulator each regime gives rise to. ${ }^{11}$ We first look at the elected regime, and then turn to the more complex appointed regime.

If the regulator is elected, candidates' preferences over public spending are immaterial. Rational voters vote on the basis of the candidates' regulatory stances and each Party has effectively two strategies: selecting a consumer or a shareholder. Under Assumption 1, for Party $A$, selecting a consumer strictly dominates selecting a shareholder. For Party $B$, the reverse is true when $\psi\left(\gamma_{C}-\gamma_{S}\right)<1$ and a shareholder has a positive probability of defeating a consumer.

Thus, if $\psi\left(\gamma_{C}-\gamma_{S}\right)<1$, Party $A$ selects a consumer, Party $B$ selects a shareholder and Party $A$ 's candidate wins with probability $\psi\left(\gamma_{C}-\gamma_{S}\right)$. If $\psi\left(\gamma_{C}-\gamma_{S}\right)=1$, Party $A$ selects a consumer and Party $B$ selects either type of candidate. In any case, a consumer is elected with probability one. Thus, we have:

Proposition 1 Suppose that Assumption 1 is satisfied. Then, if the regulator is elected, a pro-consumer regulator will be selected with probability $\psi\left(\gamma_{C}-\gamma_{S}\right)$ and a pro-shareholder regulator with probability $1-\psi\left(\gamma_{C}-\gamma_{S}\right)$.

If the regulator is appointed, gubernatorial candidates' preferences over regulation and public spending are relevant for the policy outcomes they produce. However, if Party $A$ selects a left-winger and Party $B$ a rightwinger then our assumption that citizens care more about public spending than regulation, implies that all rational voters prefer the candidate who shares their public good preferences irrespective of his stance on regulation. Thus, there is no electoral gain for either party from choosing a candidate

\footnotetext{
${ }^{11}$ As we discuss in section 5 , for welfare comparisons between the two regimes it is also necessary to understand the expected level of public spending in the two regimes.
} 
whose position on regulation differs from its ideal. Party $A$ 's candidate will therefore be a consumer and Party $B$ 's a shareholder. Since rational voters vote according to the candidates' spending preferences, Party $A$ 's candidate will win with probability $\psi\left(\gamma^{L}-\gamma^{R}\right)$.

For this to be an equilibrium, the parties must prefer to select candidates who reflect their views on public spending. Neither must want to compromise in the public spending dimension. The fact that $\gamma_{S}$ is smaller than $\gamma^{R}$ implies that Party $B$ has no incentive to do so, since such a compromise would reduce the probability that it achieves its preferred regulatory outcome and public spending level. Since $\gamma_{C}$ exceeds $\gamma^{L}$, Party $A$ will prefer a right-winger if its chances of winning a battle over public spending are sufficiently low. If $\psi\left(\gamma^{L}-\gamma^{R}\right)$ is close to zero and $\psi\left(\gamma_{C}-\gamma_{S}\right)$ close to 1 then Party $A$ will choose a type $(R, C)$ candidate despite the fact that public spending is more important to its members than regulation. We rule out this possibility with the following assumption:

Assumption 2: $\psi\left(\gamma^{L}-\gamma^{R}\right) \Delta b(L)>\left[\psi\left(\gamma_{C}-\gamma_{S}\right)-\psi\left(\gamma^{L}-\gamma^{R}\right)\right][\Delta r(C)-$ $\left.\frac{\lambda_{A}}{N \gamma_{S}} \pi\left(p^{*}(S)\right)\right]$.

The left-hand side is the expected loss in public spending benefits from a compromise on public spending, while the term on the right hand side is the expected gain in terms of regulatory price. The assumption implies that a compromise on public spending is not desirable for Party $A$. It requires that $\psi\left(\gamma^{L}-\gamma^{R}\right)$ not be "too small". ${ }^{12}$

Under Assumptions 1 and 2, Party $A$ selecting a type $(L, C)$ candidate and Party $B$ a type $(R, S)$ candidate is the unique equilibrium. Thus, we have: ${ }^{13}$

Proposition 2 Suppose that Assumptions 1 and 2 are satisfied. Then, if the regulator is appointed, a pro-consumer regulator will be selected with probability $\psi\left(\gamma^{L}-\gamma^{R}\right)$ and a pro-shareholder regulator with probability $1-\psi\left(\gamma^{L}-\gamma^{R}\right)$.

Combining the two previous propositions and recalling that $\gamma^{L}<\gamma_{C}$ yields the following result.

Proposition 3 Suppose that Assumptions 1 and 2 are satisfied. Then, a pro-consumer regulator will be selected with higher probability if the regulator is elected.

\footnotetext{
${ }^{12}$ This assumption will definitely be satisfied if $\gamma^{L} \geq \gamma^{R}$. For then $\psi\left(\gamma^{L}-\gamma^{R}\right)$ exceeds $\psi\left(\gamma_{C}-\gamma_{S}\right)-\psi\left(\gamma^{L}-\gamma^{R}\right)$ and, by assumption, $\Delta b(L)>\Delta r(C)$.

${ }^{13}$ The proof of this and subsequent results are in the Appendix.
} 
This proposition contains the basic insight as to why electing rather than appointing regulators can produce more pro-consumer outcomes. If the regulator's type is determined in a gubernatorial election, regulatory policy is bundled with other issues. Regulatory policy is unlikely to be salient for most voters and pro-business parties can run candidates with pro-business regulatory attitudes without paying an electoral penalty. The probability that these candidates win, reflects their popularity on the politically salient issues. Thus, regulatory outcomes need not reflect voters' preferences. By contrast, if the regulator is elected, then regulatory policy is bound to be salient. Election probabilities then reflect citizens' preferences over these issues.

The result rests on three critical assumptions. First, the regulatory issue is not salient for all voters. If for each citizen of type $(k, t), \Delta b(k)$ were smaller than $\Delta r(t)$, rational voters would vote on the basis of a candidate's regulatory even if the regulator were appointed. In this case, it would make no difference whether the regulator were appointed or elected. In fact, Party $B$ might even have an incentive to run a pro-consumer candidate if the regulator were appointed! ${ }^{14}$ Second, parties have different preferences on the regulatory issue. If both parties preferred pro-consumer regulators, then whether or not the regulator is elected or appointed, they would run candidates with pro-consumer regulatory stances, so that there would be no difference between the two regimes. Third, parties must offer candidates who differ in a politically salient dimension when the regulator is appointed, ensured here by Assumption 2. Without this, parties would converge in the public spending dimension, and the gubernatorial election would be fought on the candidates' stances on regulatory policy.

\subsection{Lobbying}

Producer interests tend to be much better organized than those of consumers. Hence, we now consider the implications of allowing producers to contribute to the campaigns of candidates. We assume that this takes place after the

\footnotetext{
${ }^{14}$ The intermediate cases where the regulatory issue is salient for some, but not all types of citizens, rests on detailed comparisons. If, for example, the regulatory issue is salient for shareholders and not consumers, this reinforces the effects identified in Proposition 3. If it is salient for consumers and not shareholders, a pro-consumer regulator might be more likely when the regulator is appointed.
} 
parties have selected candidates. ${ }^{15}$ These campaign contributions "buy" the votes of noise voters to enhance the election chances of pro-business candidates. Parties are assumed to rationally anticipate lobbying activities when selecting candidates.

To proceed formally, consider an election in which the difference between the campaign expenditures of the two parties' candidates is $z$. If $z$ is positive, Party $A$ 's candidate is outspending B's and vice versa. Then the fraction of noise voters voting for Party $A$ 's candidate, $\eta$, is a random variable with support $[0,1]$ and cumulative distribution function $H(\eta ; z)$. The function $H$ is assumed to be twice continuously differentiable and to satisfy the condition that for all $(\eta, z), H_{z}(\eta ; z)<0$.

To ensure that noise voters remain unbiased, we restrict $H(\eta ; z)$ to be symmetric, so that for all $\eta$ and $z, H(\eta, z)=1-H(1-\eta,-z)$. This implies that the probability that Party $A$ 's candidate gets a fraction of noise voters less than $\eta$ when he out-spends Party $B$ 's candidate by an amount $z$ equals the probability that Party $B$ 's candidate gets a fraction of noise voters less than $\eta$ when he outspends Party $A$ 's candidate by the same amount. We also assume that for all $\eta$ and $z>0, H_{z z}(\eta ; z)>0$, implying diminishing returns to outspending an opponent.

To investigate the lobby's optimal contribution, consider an election in which the identity of the regulator is to be determined and let $\omega$ be the difference between the fraction of citizens obtaining a higher utility from Party $A$ 's candidate and the fraction obtaining a higher utility from Party $B$ 's candidate. If both candidates have the same regulatory stance, the firm will make no campaign contributions. However, if Party $A$ 's candidate is a shareholder and Party B's a consumer, then the firm may contribute to Party $A$ 's candidate. Generalizing the earlier analysis, let $\widehat{\psi}(\omega, z)$ be the probability that Party $A$ 's candidate wins when the difference between the two candidate's campaign expenditures is $z \cdot{ }^{16}$ Then the firm's optimal contribution to Party $A$ 's candidate is

$$
z^{*}(\omega)=\arg \max \left\{\widehat{\psi}(\omega, z) \pi\left(p^{*}(S)\right)-z: z \geq 0\right\} .
$$

\footnotetext{
${ }^{15}$ Unlike Grossman and Helpman (1996) who combine electoral politics and lobbying, we assume that lobbies move after the parties. This approach is similar to that dicussed in Persson and Tabellini (1999) section 7.5.

${ }^{16}$ Following the earlier logic, $\widehat{\psi}(\omega, z)=0$ if $\omega \leq \frac{-(1-\mu)}{\mu}, \widehat{\psi}(\omega, z)=1$ if $\omega \geq \frac{1-\mu}{\mu}$ and $\widehat{\psi}(\omega, z)=1-H\left(\frac{-\mu \omega}{2(1-\mu)}+\frac{1}{2}, z\right)$ otherwise.
} 
If Party B's candidate is a shareholder and Party $A$ 's a consumer, the firm will contribute $z^{*}(-\omega)$ to Party $B$ 's candidate implying that Party $A$ 's candidate would win with probability $\widehat{\psi}\left(\omega,-z^{*}(-\omega)\right)$.

We make an additional technical assumption to ensure that, in a race between a consumer and a shareholder, an increase in the fraction of the population preferring the consumer candidate cannot induce a sufficiently large increase in campaign contributions to the shareholder candidate to decrease the probability that the consumer candidate wins.

Assumption 3: $H_{\eta z}(\eta ; z)<-H_{\eta}(\eta, z) \cdot H_{z z}(\eta, z) / H_{z}(\eta, z)$ for all $\eta$ and $z \geq$ 0 .

The partial derivative $H_{\eta}(\eta ; z)$ is the density of the cumulative distribution function $H(\cdot ; z)$ at $\eta$. Thus, the second partial $H_{\eta z}(\eta ; z)$ tells us how this density is changed by a marginal increase in $z$. Since the right hand side of the inequality is positive, the assumption effectively bounds the degree to which the density can increase. Under this assumption, we have:

Lemma Suppose that Assumption 3 holds, and let $\omega_{0}$ and $\omega_{1}$ be two points in $[-1,1]$ such that $\omega_{0}<\omega_{1}$. Then $\widehat{\psi}\left(\omega_{0},-z^{*}\left(-\omega_{0}\right)\right) \leq \widehat{\psi}\left(\omega_{1},-z^{*}\left(-\omega_{1}\right)\right)$ with the inequality holding strictly if $\widehat{\psi}\left(\omega_{0},-z^{*}\left(-\omega_{0}\right)\right) \in(0,1)$.

Turning to candidate selection, the parties anticipate the firm's lobbying behavior and incorporate this into the probabilities they assign to their candidates winning. Any election gives rise to a game as before, except that the election probabilities associated with different candidate pairs now incorporate the firm's lobbying behavior. Parties' strategies, strategy sets and the definition of an equilibrium are all unchanged.

If the regulator is elected, one might expect lobbying to have no effect on the parties' selection of candidates. The only effect would be that Party B's shareholder candidate would attract campaign contributions and hence would be more likely to win. However, this ignores the fact that the expenditure of resources on lobbying by the firm is wasteful and reduces the regulated firm's profits. Both parties have an incentive to avoid this rent-seeking because it reduces the payoffs of shareholders in their party. Thus, Party $A$ might have an incentive to select a shareholder when Party $B$ is running a shareholder and Party $B$ might have an incentive to select a consumer when Party $A$ is running a consumer. The following assumption rules out the first of these possibilities. 
Assumption 4: $\widehat{\psi}\left(\gamma_{C}-\gamma_{S},-\pi\left(p^{*}(S)\right)\right) \Delta r(C)>\frac{\lambda_{A}}{N \gamma_{S}} \pi\left(p^{*}(S)\right)$.

The term $\widehat{\psi}\left(\gamma_{C}-\gamma_{S},-\pi\left(p^{*}(S)\right)\right)$ represents the probability that a consumer candidate would defeat a shareholder if the shareholder received $\pi\left(p^{*}(S)\right)$ in campaign contributions. This is obviously an upper bound on the amount the firm would give and hence $\widehat{\psi}$ is a lower bound on the probability that a consumer would defeat a shareholder. Since Assumption 1 implies that $\Delta r(C)>\frac{\lambda_{A}}{N \gamma_{S}} \pi\left(p^{*}(S)\right)$, this assumption rules out the possibility that $\widehat{\psi}$ is "too low".

We now have:

Proposition 4 Suppose that the regulated firm can make campaign contributions and that Assumptions 1 and 4 are satisfied. Then, if the regulator is elected, a pro-consumer regulator will be selected if $\left[1-\widehat{\psi}\left(\gamma_{C}-\right.\right.$ $\left.\left.\gamma_{S},-z^{*}\right)\right]\left[\frac{\lambda_{B}}{N \gamma_{S}} \pi\left(p^{*}(S)\right)-\Delta r(C)\right]$ is less than $\frac{\lambda_{B}}{N \gamma_{S}} z^{*}\left(\gamma_{S}-\gamma_{C}\right)$. If the reverse inequality holds, a pro-consumer regulator will be selected with probability $\widehat{\psi}\left(\gamma_{C}-\gamma_{S},-z^{*}\right)$ and a pro-shareholder regulator with probability $1-\widehat{\psi}\left(\gamma_{C}-\right.$ $\left.\gamma_{S},-z^{*}\right)$.

To understand this, observe that Assumption 4 guarantees that Party $A$ will always select a consumer. ${ }^{17}$ The inequality stated in the Proposition determines whether or not Party $B$ 's best response is to select a consumer or a shareholder. Choosing a consumer might be optimal for Party $B$ because it avoids the costs that the firm's rent-seeking imposes on its shareholder members. Thus, if the inequality holds, lobbying by the regulated firm actually creates an outcome that favors lower prices and the regulated firm would prefer to commit not to lobby. When the reverse inequality holds, the lobby supports Party B's candidate and increases the likelihood of him/her being elected.

When the regulator is appointed, allowing campaign contributions raises a consideration not arising in the case of election. Suppose that Party $A$ is running a type $(L, C)$ candidate and Party $B$ a type $(R, S)$ candidate. Then the regulated firm's support of Party $B$ 's candidate will increase the probability that he/she wins. Party $A$ now has an incentive to neutralize this advantage by selecting a shareholder. While costly in terms of its regulatory objectives, this compromise in the regulatory dimension will increase

\footnotetext{
${ }^{17}$ Without Assumption 2, there exist conditions under which both parties choosing shareholders is an equilibrium.
} 
the probability of Party $A$ achieving its members' preferred public spending outcome. Such electoral considerations also increase Party $B$ 's incentive to select a shareholder.

To restrict the range of possible cases, we strengthen Assumption 2 in the following way.

Assumption 5: $\psi\left(\gamma^{L}-\gamma^{R}\right) \Delta b(L)>\left[\Delta r(C)-\frac{\lambda_{A}}{N \gamma_{S}} \pi\left(p^{*}(S)\right)\right]$.

This rules out any compromise in the public spending dimension by Party $A$. By selecting a type $(L, S)$ candidate when Party $B$ selects a type $(R, S)$ candidate, Party $A$ can neutralize the impact of the lobby and make the election a referendum on the public spending issue. In such an election, Party $A$ 's candidate wins with probability $\psi\left(\gamma^{L}-\gamma^{R}\right)$. Assumption 5 implies that this strategy dominates one in which Party $A$ compromises on the public spending dimension to increase the likelihood of its preferred regulatory outcome.

We now have:

Proposition 5 Suppose that the regulated firm can lobby by making campaign contributions and that Assumptions, 1, 3 and 5 are satisfied. Then, if the regulator is appointed, a pro-shareholder regulator will be selected if $\widehat{\psi}\left(\gamma^{L}-\gamma^{R},-z^{*}\right)\left[\Delta r(C)-\frac{\lambda_{A}}{N \gamma_{S}} \pi\left(p^{*}(S)\right)\right]$ is less than $\left[\psi\left(\gamma^{L}-\gamma^{R}\right)-\widehat{\psi}\left(\gamma^{L}-\right.\right.$ $\left.\left.\gamma^{R},-z^{*}\right)\right] \Delta b(L)+\frac{\lambda_{A}}{N \gamma_{S}} z^{*}\left(\gamma^{R}-\gamma^{L}\right)$. If the reverse inequality holds, a proconsumer regulator will be selected with probability $\widehat{\psi}\left(\gamma^{L}-\gamma^{R},-z^{*}\right)$ and a pro-shareholder regulator with probability $1-\widehat{\psi}\left(\gamma^{L}-\gamma^{R},-z^{*}\right)$.

In equilibrium, Party $B$ selects a type $(R, S)$ candidate. Not only does Party $B$ prefer a shareholder, but running a shareholder attracts campaign contributions which increase the probability that it receives its preferred public spending level. The latter explains why Party $B$ never runs a consumer to avoid the costs of rent seeking. The inequality in the Proposition determines whether Party $A$ would rather pick a shareholder or a consumer as a candidate in response. Picking a consumer reduces the probability that it receives its preferred spending level and triggers costly rent seeking. However, it increases the likelihood of it obtaining its preferred regulatory price. These benefits are represented by the left hand side of the inequality and the costs by the right hand side. The case in which the benefits are less than the costs illustrates why it could be misleading to look at equilibrium payments to gauge the power of lobbies. The regulated firm has a significant impact on the policy outcome without making any campaign contributions! Its power 
stems from the credible threat to support Party $B$ 's candidate if Party $A$ puts up a consumer.

Combining the two previous propositions and using the Lemma, yields

Proposition 6 Suppose that the regulated firm can lobby by making campaign contributions and that Assumptions 1, 3, 4 and 5 are satisfied. Then, a pro-consumer regulator will be chosen with higher probability if the regulator is elected.

This demonstrates the robustness of the basic insight from the previous section. In fact, incorporating the effects of lobbying creates two additional reasons why electing regulators can promote consumer interests. First, electing a regulator can induce Party $B$ to choose a consumer to avoid the costly rent seeking that a consumer versus shareholder race produces. Second, if the regulator is appointed, then each party has an incentive to pander to the regulated firm to avoid the electoral disadvantage that running a proconsumer candidate creates. This electoral disadvantage is costly because it reduces the probability of a party achieving its preferred public spending level. Thus, the fact that regulation is bundled with other issues increases the power of the lobby. This effect implies that, even if Assumption 1 is violated and both parties favored pro-consumer candidates, they might be induced to run pro-shareholder candidates in the gubernatorial election in the situation where the regulator is appointed. ${ }^{18}$

\subsection{Other considerations}

Here we briefly discuss a number of other considerations which seem both practically relevant and important for our results. First, it might be argued that, because the issues are less important, a greater fraction of the electorate would vote in a noisy way in regulator than gubernatorial elections. This idea can be formalized by supposing that a fraction $\mu_{1}$ of the population are

\footnotetext{
${ }^{18}$ These conclusions depend on the approach to lobbying adopted here. An alternative plausible scenario is that regulated firms lobby regulators after they have been selected, by offering promises of future employment and other types of bribes to regulators in exchange for policy favors (see, for example, Laffont and Tirole (1993), Grossman and Helpman (1994) and Besley and Coate (1999)). In this case, the ability of the regulator selection mechanism to mute the regulated firm's influence is more limited. Even the staunchest pro-consumer regulator may find it difficult not to be swayed by the prospect of significant personal gain.
} 
rational voters in regulator elections and a fraction $\mu_{2}$ are rational voters in gubernatorial elections with $\mu_{1}<\mu_{2}$. These different fractions would give rise to different probability of winning functions $\psi_{1}(\omega)$ and $\psi_{2}(\omega)$ for the two types of elections. It should be clear that, even if parties selection of candidates remain as described above, the conclusions of Propositions 3 and 6 might need to be modified. It is possible, for example, that $\psi_{1}\left(\gamma_{C}-\gamma_{S}\right)$ might be less than $\psi_{2}\left(\gamma^{L}-\gamma^{R}\right)$, undermining the argument that electing regulators results in more pro-consumer outcomes. ${ }^{19}$

In similar vein, it might be argued that, if regulator and gubernatorial elections were held simultaneously, voters would vote a party ticket, with party preferences being determined by their preferred gubernatorial candidate. Thus voters' party preference would be determined by the "top of the ticket" and there would be a "coat-tail effect" for regulator candidates. If all voters behaved in this way, then there would be no difference between electing and appointing regulators under our assumptions. If the regulator is elected, each party would select its preferred type of regulator as in Proposition 1 , but the probability that Party $A$ 's candidate would win (and hence that the regulator would be of type $C$ ) would simply be $\psi\left(\gamma^{L}-\gamma^{R}\right)$.

Finally, it might be argued that the logic underlying Proposition 3 rests on the assumption that only the two political parties can offer candidates, with entry by independent "citizen-candidates" being ruled out. Party $B$ is able to "get away" with selecting an $(R, S)$ candidate only because there is no candidate of type $(R, C)$ in the race. With citizen-candidates, the threat of entry by an independent type $(R, C)$ candidate might force Party $B$ to run such a candidate itself. However, this argument neglects the difficulties inherent in elections with three or more candidates. If rational voters vote sincerely, entry by a type $(R, C)$ independent would simply split the rightwing vote and significantly enhance the probability of the left-wing candidate winning. If rational voters are strategic, right wingers will be reluctant to switch to the entrant for fear of wasting their vote. ${ }^{20}$ Thus, a type $(R, C)$ independent is likely to either increase the probability of the left wing candidate winning or to have no effect. Either way, such a candidate has little

\footnotetext{
${ }^{19}$ Suppose that $1 / 2$ the population are rational voters in gubernatorial elections, and $1 / 4$ in regulator elections. Further suppose that $3 / 4$ of the population are consumers and $2 / 3$ left-wingers. Then in the gubernatorial election, the left wing candidate will win if $\eta$ exceeds $1 / 3$. In the regulator election, the consumer candidate will also win if $\eta$ exceeds $1 / 3$. Thus, Proposition 3 is violated.

${ }^{20}$ See, for example, Besley and Coate (1997) for elaboration of this argument.
} 
incentive to enter.

\section{Evidence}

Our theory provides a number of reasons to believe that a regime in which regulators are directly elected might produce more pro-consumer regulators than a regime in which they are appointed. In the remaining part of the paper, we investigate whether the data suggest that U.S. states which elect their public utility regulators do indeed have more pro-consumer regulators. Each state has its own regulatory commission, with the two basic selection methods being direct election and appointment by the state governor. ${ }^{21}$ The regulatory commissions perform a variety of functions (see Phillips (1988) chapter 4) including granting permits and licenses. However, for our purposes, their most important function is the control of retail rates for electricity in the states in which they operate. ${ }^{22}$ We use data on electricity prices to test whether regulators in directly elected states are more pro-consumer. Our data come from the EEI and give prices of electricity in three segments of the market - residential, commercial and industrial from 1960 to 1997 for all continental U.S. States. We first test whether prices are lower in those states that elect their electricity regulators and then examine whether prices are less sensitive to cost shocks in elected states.

\subsection{Price levels}

At the beginning of our period (1960), fourteen states elected their utility commissioners, falling to twelve by the end (1997). This general trend masks the fact that five states switched their method of selecting regulators. ${ }^{23} \mathrm{We}$ summarize some information about the differences in characteristics of the three categories of states (appointers, electors and switchers) in Table 1.

\footnotetext{
${ }^{21}$ The data appendix gives all the variations observed in the data. Appendix Table 2 gives a list of states in each category.

${ }^{22}$ As Joskow (1974) has argued, it is price regulation that ultimately influences the rate of return that the industry enjoys.

${ }^{23}$ Florida switched from electing to appointing in 1981; Iowa switched to an election system for 1962 and 1963 only; Minnesota has the most colorful history, using an election system 1960-71, appointing from 1972-5, electing from 1976-77 and appointing ever since; South Carolina switched to an election system in 1996; Texas switched from an election to an appointment system in 1977.
} 
States that elect their utility commissioners tend to be smaller and poorer than states that appoint them. They are also more likely to have a democratic governor. However, the states are similar in terms of demographic structure as measured by the proportion of children and their population aged over 65 . There is no significant difference between the states that appoint and elect their utility commissioners in terms of the proportion of electricity produced from fossil fuels (around $70 \%$ for both kinds of states).

Table 1 also provides information on the raw means of the nominal prices of electricity (denoted in cents per kilowatt hour) across the three types of states. ${ }^{24}$ If states with elected regulators have more pro-consumer regulators, we would expect them to have lower prices. The results give an immediate suggestion that electors have lower prices than appointers - the difference is statistically significant at $5 \%$ for residential rates and at $10 \%$ for commercial and industrial rates. This finding is only suggestive - there are a host of reasons why prices may differ which are not controlled for in the means. Hence, for a slightly more sophisticated approach, we regressed the price series on state dummy variables and year dummy variables. We then saved the state dummy variables and regressed them on whether the state elects or appoints its regulators. The results in Table 2 confirm that there is a statistically significant difference in prices between electors and appointers. ${ }^{25}$ To put this difference into perspective, at the mean household consumption of 10,000 kilowatt hours per annum, it implies a difference of around $\$ 60$ per annum on an average household's electricity bills. ${ }^{26}$

Joskow (1974) observes that the influence of regulators on prices is likely to be much more important in an environment where input prices are rising, since rate reviews are most likely in such periods. According to this argument, regulator influence should become more important in the post-1969 period when fossil fuel prices increased dramatically. This increase is documented in Figure 1 which graphs a composite fossil fuel price index (gas, coal and oil) over time per BTU (the variable ffcomp). The turbulent period from 1969 to the mid 1980s here is evident. The graph also shows our series on the

\footnotetext{
${ }^{24}$ We conduct the analysis in terms of nominal prices. Similar results are obtained when prices are deflated using the consumer price index.

${ }^{25}$ For the purposes of these regressions, we excluded the states who switched regime.

${ }^{26}$ The fact that price differentials between electing and appointing states vary across the different tariffs can be explained by the fact that price increases in each case can impact consumers differently. In a more general model, regulators could also attach different weights to different groups of consumers.
} 
residential price of electricity (mrpk) and a state specific fossil fuel cost index per BTU (mcost). The latter is generated by multiplying the share (in total production) of electricity produced using each type of fossil fuel measured in BTUs weighted by a price series obtained from Energy Information Agency's Annual Energy Review. The residential price increased along with costs in the 1970 s and kept on doing so after costs declined in the late 1980s. ${ }^{27}$

To investigate the changing importance of regulator influence, we check whether the gap between appointers and electors widened between 1970 and 1980. We do a simple difference-in-difference analysis in Table 3. The average residential price per kilowatt hour between elected and appointed states was 0.3 cents in the 1960s and increased to 1 cent in the 1970s. This widening gap is statistically significant at conventional levels. There are similar changes (also significant) for commercial and industrial prices. Both of these findings from the raw data are well illustrated in Figure 2 which plots the mean residential price per kilowatt hour for states that appoint (marpk) and that elect (merpk). This illustrates both the differences in means and the divergence during the 1970s.

\subsection{Responsiveness to cost shocks}

Our second test is motivated by the theoretical observation that prices set by more pro-consumer regulators should be less responsive to cost shocks. To see this, suppose (following standard practice) that regulators choose prices to maximize $N r(p, C)+\lambda \pi(p)$ subject to the constraint that $\pi(p) \geq 0$ for some weight $\lambda$. The degree to which a regulator is "pro-consumer" is then measured by the relative weight he/she places on consumer relative to producer surplus. Our model represents a special case of this general formulation, with the weight a regulator puts on the profits of the regulated firm determined by his/her connection to the firm. Further suppose that the regulated firm's cost function is $c(x)=F+c \cdot x$ and let $p^{*}(c, \lambda)$ be a type $\lambda$ regulator's optimal price given the marginal cost $c$. Assuming that $\pi\left(p^{*}(c, \lambda)\right)>0$, it may readily be shown that

\footnotetext{
${ }^{27}$ However, the picture is somewhat different when looking at real rather than nominal prices. The 1960s saw falling real prices while prices increased in real terms in the 1980s. Real prices have been declining since.
} 


$$
p^{*}(c, \lambda)=\frac{c}{1-\frac{\left(1-\frac{1}{\lambda}\right)}{\varepsilon}},
$$

where $\varepsilon$ is the price elasticity of demand. Assuming that consumer demand functions are of the constant elasticity form, it is clear that $p_{c}^{*}(c, \lambda)<$ $p_{c}^{*}\left(c, \lambda^{\prime}\right)$ for $\lambda<\lambda^{\prime} .^{28}$ This result is consonant with Joskow (1974)'s description of the regulatory process that emphasizes the dynamics of rate increases in response to costs to shocks. Pro-consumer regulators should be less willing to respond to applications for rate increases by utilities in the face of cost shocks.

To implement the test requires a measure of such cost shocks over the data period. This is not entirely straightforward as states use a variety of production methods. Moreover, these vary in the relative importance of fixed and variable costs. In reviewing the available technologies, Turvey and Anderson (1977) contrast the low marginal cost technologies of hydro and nuclear with higher marginal cost technologies of fossil fuels. (The three main fossil fuel sources are gas, coal and oil.) Hydro generation and nuclear power tend, on the whole, to have higher fixed costs. It is much easier to get series that capture changes in the prices of fossil fuels which, Figure 1 showed, have experienced dramatic price changes. Hence, here we focus on shocks to these costs. However, it is clear that states will have very different susceptibilities to these costs on account of their varying production structures. We therefore use the variable mcost described above as our measure of costs. Denote this variable $c_{s t}$ in state $s$ at time $t$.

This allows us to run panel regressions of the form:

$$
p_{s t}=\alpha_{s}+\beta_{t}+\gamma_{1} \delta c_{s t}+\gamma_{2}(1-\delta) c_{s t}+\phi x_{s t}+\varepsilon_{s t}
$$

where $p_{s t}$ is the average price per kilowatt hour for state $s$ in year $t ; \alpha_{s}$ are state fixed effects proxying for long-run differences in states' production and

\footnotetext{
${ }^{28}$ This also holds for the boundary where $\pi\left(p^{*}(c, \lambda)\right)=0<\pi\left(p^{*}\left(c, \lambda^{\prime}\right)\right)$ as long as $\varepsilon \leq 1$ which is the empirically relevant case for electricity demand. To see this, observe that $p^{*}(c, \lambda)$ satisfies the price equals average cost equation $p^{*}=c+F / N x\left(p^{*}\right)$. This equation implies that $\partial p^{*}(c, \lambda) / \partial c=1 /\left[1-\frac{\varepsilon\left(p^{*}(c, \lambda)-c\right)}{p^{*}(c, \lambda)}\right]$. Thus, using the expression for $p^{*}\left(c, \lambda^{\prime}\right)$ given in the text and noting that $\left[1-1 / \lambda^{\prime}\right] / \varepsilon=\frac{p^{*}\left(c, \lambda^{\prime}\right)-c}{p^{*}\left(c, \lambda^{\prime}\right)}$, we have that $\frac{\partial p^{*}(c, \lambda)}{\partial c}<\frac{\partial p^{*}\left(c, \lambda^{\prime}\right)}{\partial c}$ if $\frac{\varepsilon\left(p^{*}(c, \lambda)-c\right)}{p^{*}(c, \lambda)}<\frac{p^{*}\left(c, \lambda^{\prime}\right)-c}{p^{*}\left(c, \lambda^{\prime}\right)}$. Since $p^{*}(c, \lambda)<p^{*}\left(c, \lambda^{\prime}\right)$, a sufficient condition for the result is that $\varepsilon \leq 1$.
} 
distribution systems due to climate etc; $\beta_{t}$ are year dummy variables that pick up macro-shocks and common changes in federal policy; $x_{s t}$ is a vector of state specific, time varying shocks; and $\delta$ is a dummy variable that is equal to one if the state elects its regulator. The key implication to be tested is that $\gamma_{1}<\gamma_{2}$; i.e. prices should respond less to cost shocks when states elect their regulators.

The basic results are given in Table $4 .{ }^{29}$ Columns (1) through (3) give results in each of three categories of provision where differences between states and over time are controlled for solely with state and year effects. The key observation is that the coefficient on costs for electors is everywhere below that for appointers. Row three of the table gives the results of an F-test on the equality of these coefficients - the hypothesis of equality is rejected comfortably in every case. This is robust to including a number economic controls as in columns (4)-(6).

To get an idea of differences across the different types of electricity tariffs, it is worth looking at the ratio of the effect of a cost increase in elected and appointed states. The ratio of these coefficients is roughly 3-1 for residential (column 4), 6-5 for commercial and 7-5 for industrial. This suggests that the biggest effect of being elected is on residential prices. This is line with the results that we found for price levels reported above.

To put the size of the coefficients in perspective, we can use the estimated coefficients in table 4 to see how much of the divergence in prices between the pre 1970 and 1970-85 period reported in table 3 can be explained. Here, we observed increases in the price differential of 0.7 cents for residential prices, 0.6 cents for commercial and 0.4 cents for industrial users. Using, the coefficients from columns 3-6 in table 4 and the actual cost increase over the period, we would predict increases in the price differential of 0.31 cents for residential users, 0.07 cents for commercial prices and 0.2 cents for industrial users.

Looking at the other coefficients in the final three columns of Table 4, we find that both population and income per capita exert significant effects on electricity prices. Evaluated at the mean, these coefficients imply that higher income per capita exerts an upward effect on electricity prices, while higher population has the opposite effect. We also find that states that have

\footnotetext{
${ }^{29}$ Appendix Table 1 reproduces the basic results excluding the five states that switched their method of selecting regulators during our time period. The results are not sensitive to doing this.
} 
more old people in them have higher electricity prices. These effects can be interpreted as reflecting state specific demand conditions.

If one looks at an index of fossil fuel prices over our data period, things fall into three fairly distinct periods. The 1960s saw rather stagnant prices, followed by a period of rising prices, peaking in the mid 1980s since when nominal input prices have been falling. Following Joskow (1974), we look to see whether the effect of regulatory institutions are most apparent in the middle period. The first three columns in Table 5 give the results when we split the sample into three sub periods - 1960-69, 1970-85 and 1985-97. The results are consistent with the idea that the main period driving the results is the middle period of our data when there were big changes in energy prices.

Overall, these results confirm the idea that electing public utility commissioners lead to regulatory outcomes that are more favorable to consumers. This was particularly true in the turbulent years of the 1970s when fossil fuel prices were repeatedly shocked by international events.

\section{Discussion}

The above results do not tell us who is paying for lower prices in states that elect their regulators. In the theoretical model, lower prices simply shift rents from shareholders to consumers. In this case, the welfare conclusions depend upon the relative weights that are placed on the payoffs of these two groups. Assuming that the probability distribution over public spending is the same under both regimes, electing utility commissioners is welfare enhancing if and only if this rent transfer is desirable. ${ }^{30}$

However, it is likely that lower prices have effects on other decisions, particularly the decision to invest. In the early years of U.S. utility regulation, the negative effects of regulator populism on incentives to invest was an abiding concern (see Troesken (1997)). Indeed, in part, this was behind the reason why the utilities themselves lobbied in favor of state level utility

\footnotetext{
${ }^{30}$ With lobbying, the probability distribution over public spending may differ across regimes. To see this, suppose that with appointed regulators, Party $A$ selects a type $(L, C)$ gubernatorial candidate and Party $B$ a type $(R, S)$, and with elected regulators, Party $A$ selects a type $L$ gubernatorial candidate and a type $C$ regulator, while Party $B$ selects a type $R$ gubernatorial candidate and a type $S$ regulator. Then, since the lobby will support Party B's gubernatorial candidate in the appointed case, expected public spending will be higher when regulators are elected. This must be taken into account in the welfare calculation.
} 
regulations to replace regulation at the local level. Once a utility had sunk its capital, it was reliant on the regulator to allow prices commensurate with earning an acceptable rate of return. Locally accountable regulators were more likely to be tempted to lower prices in order to gain popularity. In his study of gas companies, Troesken (1997) observes that "state utility commissions helped local governments credibly commit to reasonable regulatory policies. This made it easier for cities and towns to attract private capital. State regulation helped local governments commit because gas companies believed that state regulators were more sympathetic to producers than were local regulators (page 9)." This brings into sharp relief the possible dilemma of populist regulation in a dynamic framework. ${ }^{31}$

Service reliability remains an important concern of regulators in the United States. Moreover, there is a feeling that there are important interactions between price regulation and service quality (see, for example Phillips (1988) page 507). This type of argument suggests that we might expect to see less investment in the electricity network in states that elect their regulators given our finding that prices are lower in these states. While a full-blown analysis of investment decisions lies beyond the scope of the current paper, we are able to get some evidence on this issue, by looking to see whether states that elect their regulators appear to offer a less reliable electricity service to their consumers. To consider this, we obtained data on the number of power interruptions experienced in the States between 1984 and 1997. We use these data to investigate whether there is any relationship with regulator selection methods. Since the data in question are count data, we use a Poisson regression model.

The results are given in Table 6 . In the first column, we include only year dummy variables to control for common shocks to reliability in all of the States. The results show that there is a significantly higher number of interruptions in the States that elect their regulators. This result is robust to controlling for the economic and demographic variables that we included in the first tables. It is not, however, robust to allowing for random effects (columns (3) and (4)). Overall, there is weak, but inconclusive, evidence suggesting that states that elect their utility commissioners have greater numbers of interruptions.

We can also try to measure the extent to which states are responsive to

\footnotetext{
${ }^{31}$ These hold-up problem type of issues are recognized in the extensive theoretical literature on regulation - see, for example, the discussion in Laffont and Tirole (1993).
} 
past power interruptions. In general, we would expect states that have experienced more power problems in the past to make a larger effort to invest in future. However, we would expect the incentive to invest to be smaller in states that elect their utility commissioners. To investigate this, we created a variable that measures the past stock of power interruptions in each state. We then entered this into our regression, this time allowing for state fixed effects. However, we allowed it take on a different coefficient in the regression depending on whether the state elected or appoints its regulatory commissioners. The results are in Table 6, column (5). This shows that states that appoint their regulatory commissioners are more responsive to past power interruptions than those that elect them. This provides some evidence that investment in quality is lower in states that appoint their regulators. Overall, this suggests that a full-blown welfare analysis should take into consideration the possibility that investment responds to the regime for electing regulators. ${ }^{32}$

We have interpreted our results as reflecting the importance of the rule for the selection of utility commissioners. However, it is possible that being elected is proxying for other dimensions of regulatory rules. ${ }^{33}$ It is interesting to note that Navarro (1982) finds that states that elect their regulators show a more unfavorable regulatory climate according to his rankings of states gleaned from a number of commercial organizations. This is consistent with our findings although it is possible that states with elected commissioners also have stronger regulatory institutions. However, looking at the measures from Norton (1985), the only states that elected commissioners in his sample were classified as weakly regulated (Norton (1985) Table 1). ${ }^{34}$ Gormley (1981) observes that consumer movements are much more likely to be active in states where the public utility commissioner is appointed.

The analysis assumes that whether a state elects or appoints its regulators is exogenous. Endogeneity of this kind of institutional choice is a problem if states make their decision in response to unobservables that affect pricing

\footnotetext{
${ }^{32}$ Laffont and Tirole (1993, page 102) suggests that the length of term of the regulators should also matter for their ability to commit and hence to investment incentives. Interacting this with the past stock of power interruptions, we find that states with longer terms do appear more responsive as their analysis suggests.

${ }^{33}$ When we interact cost variable with other variables in Table 1 that differ across states that elect and appoint their public utility commissioners, this does not disturb the basic finding presented in that table.

${ }^{34}$ See also Costello (1984) Table 7.
} 
decisions over electricity. Thus, the fact that some states switched is not evidence per se of a problem. Moreover, the results in the Appendix table show that the results are robust to excluding the observations from those states who switched during our data period. While ideally, we would instrument for the institutional choice, there is no natural instrumental variable available in our context.

The analysis reported here does not exploit other dimensions of state regulatory policy such as the length of terms served by commissioners, the level of payment to regulators and the sources of funding for regulatory commissions. When we included such variables in the analysis, no consistent pattern in relation to pricing decisions emerged. ${ }^{35}$ However, clearly there is further work to be done on these other aspects of regulatory decisions.

\section{Concluding Comments}

This paper has identified some theoretical arguments that electing regulators will lead to more pro-consumer regulators. If regulators are appointed, the type of regulator selected is more likely to reflect the preferences of party elites or lobby groups than those of the voters at large. This is because regulation is unlikely to be politically salient in general elections. Parties can then follow the non-majoritarian preferences of their members or sell out to lobbies without facing an electoral penalty. If regulators are elected, their stance on regulation is the only salient issue so that the regulator is more likely to be of the type favored by the majority of citizens. Empirical support for these arguments comes from the paper's finding that states that elect their regulatory commissioners have lower electricity prices and raise prices by a lower amount when costs increase.

These findings have significant implications for choosing the appropriate scope for voting mechanisms in determining policies. If elected representatives must decide on numerous policy issues, it is reasonable to expect that many will not be politically salient. Our arguments suggest that such issues give an entree to elites within parties and/or lobby groups. By separating out these issues and directly electing policy-makers to decide on them,

\footnotetext{
${ }^{35}$ We also interacted our cost variables with other state characteristics (e.g. income and population) that Table 1 reveals are different in the electing and appointing states. This did not disturb our basic result that states that elect put up prices less in response to fossil fuel price shocks.
} 
citizen power can be enhanced. While there is no general claim about the welfare impact of such changes, it is important to understand the mechanisms through which policy outcomes can be made more congruent with citizens' preferences. 


\section{References}

[1] Baldwin, Robert, and Martin Cave, [1999], Understanding Regulation: Theory, Strategy and Practice, Oxford: Oxford University Press.

[2] Baron, David, [1988], "Regulation and Legislative Choice," Rand Journal of Economics, 20, 467-77.

[3] Baron, David, [1994], "Electoral Competition with Informed and Uninformed Voters," American Political Science Review, 88, 593-609.

[4] Baron, David, [1995], "The Economics and Politics of Regulation: Perspectives, Agenda and Approaches," in Jeffrey Banks and Eric Hanushek (eds), Modern Political Economy, Cambridge: Cambridge University Press.

[5] Berry, William, [1979], "Utility Regulation in the States: The Policy Effects of Professionalism and Salience to the Consumer," American Journal of Political Science, 23(2), 263-277.

[6] Besley, Timothy and Stephen Coate, [1997], "An Economic Model of Representative Democracy", Quarterly Journal of Economics, 112(1), 85-114.

[7] Besley, Timothy and Stephen Coate, [1999], "Lobbying and Welfare in a Representative Democracy", Review of Economic Studies, forthcoming.

[8] Costello, Kenneth W., [1984], Electing Regulators: The Case of Public Utility Commissioners, Yale Journal on Regulation, 2, 83-105.

[9] Crain, W. Mark and Robert E. McCormick, [1984], "Regulators as an Interest Group," in James M. Buchanan and Robert D. Tollison (eds), The Theory of Public Choice II, Ann Arbor: University of Michigan Press.

[10] Gormley, William T., [1981], "Non-electoral Participation as a Response to Issue-specific Conditions: The Case of Public Utility Regulation," Social Science Quarterly, 62(3), 527-539.

[11] Grossman, Gene and Elhanan Helpman, [1994], "Protection for Sale," American Economic Review, 88, 139-156. 
[12] Grossman, Gene and Elhanan Helpman, [1996], "Electoral Competition and Special Interest Politics," Review of Economic Studies, 63(2), 26586.

[13] Harris, Malcolm C., and Peter Navarro, [1983], "Does Electing Public Utility Commissioners Bring Lower Electric Rates?" Public Utilities Fortnightly, 112 (sept.), 23-88.

[14] Joskow, Paul, [1974], "Inflation and Environmental Concern: Structural Change in the Process of Public Utility Regulation," Journal of Law and Economics, 291-327.

[15] Joskow, Paul and Roger Noll, [1981], "Regulation in Theory and Practice: An Overview," in Gary Fromm (ed), Studies in Public Regulation, Cambridge, MA: MIT Press.

[16] Joskow, Paul and Nancy Rose, [1989], "The Effects of Economic Regulation," in Richard Schmalensee and Robert Willig (eds), Handbook of Industrial Organization, Amsterdam: North Holland.

[17] Laffont, Jean-Jacques, [1996], "Industrial Policy and Politics," International Journal of Industrial Organization, 14(1), 1-27.

[18] Laffont, Jean-Jacques and Jean Tirole, [1993], A Theory of Incentives in Procurement and Regulation, Cambridge MA: MIT Press.

[19] Navarro, Peter, [1982], "Public Utility Commission Regulation: Performance, Determinants and Energy Policy Impacts," The Energy Journal, $3(2), 119-139$.

[20] Norton, Seth W., [1985], "Regulation and Systematic Risk: The Case of Electric Utilities," Journal of Law and Economics, 28, 671-686.

[21] Osborne, Martin and Al Slivinski, [1996], "A Model of Political Competition with Citizen-Candidates," Quarterly Journal of Economics, 111, 65-96.

[22] Peltzman, Sam, [1976], "Toward a More General Theory of Regulation," Journal of Law and Economics, 19, 211-40. 
[23] Persson, Torsten and Guido Tabellini, [1999], Political Economics: Explaining Economic Policy, book manuscript forthcoming from MIT Press.

[24] Phillips, Charles F. Jr, [1988], The Regulation of Public Utilities, Arlington, VA: Public Utilities Reports, Inc.

[25] Primeaux, Walter and Patrick Mann, [1986], "Regulator Selection Methods and Electricity Prices," Land Economics, 63(1), 1-13.

[26] Stigler, George, [1971], "The Theory of Economic Regulation," The Bell Journal of Economics, Spring, 3-21.

[27] Stigler, George and C. Friedland, [1962], "What the Regulators Regulate? The Case of Electricity," Journal of Law and Economics, 5, 1-16.

[28] Troesken, Werner, [1997], "The Sources of Public Ownership: Historical Evidence from the Gas Industry," Journal of Law, Economics and Organization, 13(1), 1-25.

[29] Turvey, Ralph and Dennis Anderson, [1977], Electricity Economics: Essays and Case Studies, Baltimore: Johns Hopkins University Press. 


\section{Appendix}

\subsection{Proofs}

Proof of Proposition 2: We will show that the game defined by the gubernatorial election when the regulator is appointed has a unique equilibrium in which Party $A$ selects a candidate of type $(L, C)$ and Party $B$ a candidate of type $(R, S)$. The first point to note is that, for Party $A$, the strategy $(L, C)$ strictly dominates all its other strategies. It should be clear that $(L, C)$ strictly dominates the strategies $(R, S)$ and $(L, S)$, so we concentrate on the comparison between $(L, C)$ and $(R, C)$. The only non-obvious case is that in which Party $B$ is choosing a type $(R, S)$ candidate. Party $A$ 's expected payoff from choosing a candidate of type $(L, C)$ is:

$$
\psi\left(\gamma^{L}-\gamma^{R}\right) W_{A}\left(g^{*}(L), p^{*}(C)\right)+\left[1-\psi\left(\gamma^{L}-\gamma^{R}\right)\right] W_{A}\left(g^{*}(R), p^{*}(S)\right),
$$

while that from choosing a type $(R, C)$ candidate is

$$
\psi\left(\gamma_{C}-\gamma_{S}\right) W_{A}\left(g^{*}(R), p^{*}(C)\right)+\left[1-\psi\left(\gamma_{C}-\gamma_{S}\right)\right] W_{A}\left(g^{*}(R), p^{*}(S)\right) .
$$

Subtracting the latter from the former, the difference can be expressed as:

$$
\psi\left(\gamma^{L}-\gamma^{R}\right) \Delta b(L)-\left[\psi\left(\gamma_{C}-\gamma_{S}\right)-\psi\left(\gamma^{L}-\gamma^{R}\right)\right]\left[\Delta r(C)-\frac{\lambda_{A}}{N \gamma_{S}} \pi\left(p^{*}(S)\right)\right]
$$

This is positive by Assumption 2 .

It follows that in any equilibrium Party $A$ must be choosing a type $(L, C)$ candidate. But Party $B$ 's best response to a type $(L, C)$ candidate is clearly to choose a type $(R, S)$ candidate. Choosing a type $(R, C)$ candidate does not effect its probability of winning, but reduces its payoff from winning, while choosing a type $(L, S)$ candidate both reduces its chances of winning and its payoff from winning. QED

Proof of Lemma: As pointed out in footnote 16, $\widehat{\psi}\left(\omega,-z^{*}(-\omega)\right)=0$ if $\omega \leq \frac{-(1-\mu)}{\mu}, \widehat{\psi}\left(\omega,-z^{*}(-\omega)\right)=1$ if $\omega \geq \frac{1-\mu}{\mu}$ and $\widehat{\psi}\left(\omega,-z^{*}(-\omega)\right)=1-$ $H\left(\frac{-\mu \omega}{2(1-\mu)}+\frac{1}{2},-z^{*}(-\omega)\right)$ otherwise. It is clear that the result holds if either $\omega_{0}$ $\leq \frac{-(1-\mu)}{\mu}$ or if $\omega_{1} \geq \frac{1-\mu}{\mu}$. Thus, we may assume that $\frac{-(1-\mu)}{\mu}<\omega_{0}<\omega_{1}<\frac{1-\mu}{\mu}$. 
It is clear that the result must hold if $z^{*}\left(-\omega_{0}\right) \geq z^{*}\left(-\omega_{1}\right)$, so we may assume that $0 \leq z^{*}\left(-\omega_{0}\right)<z^{*}\left(-\omega_{1}\right)$.

For all $\omega \in\left[\omega_{0}, \omega_{1}\right]$, we have that:

$$
z^{*}(-\omega)=\arg \max \left\{\left[1-H\left(\frac{\mu \omega}{2(1-\mu)}+\frac{1}{2}, z\right)\right] \pi\left(p^{*}(S)\right)-z: z \geq 0\right\}
$$

which implies that $z^{*}(-\omega)$ is defined by the condition that

$$
-H_{z}\left(\frac{\mu \omega}{2(1-\mu)}+\frac{1}{2}, z^{*}(-\omega)\right) \pi\left(p^{*}(S)\right) \leq 1 \text { with equality if } z^{*}(-\omega)>0 .
$$

Now define the set

$\Omega=\left\{\omega \in\left[\omega_{0}, \omega_{1}\right]:-H_{z}\left(\frac{\mu \omega}{2(1-\mu)}+\frac{1}{2}, z^{*}\left(-\omega_{0}\right)\right) \leq-H_{z}\left(\frac{\mu \omega_{0}}{2(1-\mu)}+\frac{1}{2}, z^{*}\left(-\omega_{0}\right)\right)\right\}$.

Since the function $H$ has continuous derivatives, this set is compact. Letting $\omega^{*}=\max \{\omega: \omega \in \Omega\}$, it is clear that $z^{*}\left(-\omega^{*}\right)=z^{*}\left(-\omega_{0}\right)$ and that $z^{*}(-\omega)>$ $z^{*}\left(-\omega_{0}\right) \geq 0$ for all $\omega \in\left(\omega^{*}, \omega_{1}\right]$. In addition, since $\omega^{*} \geq \omega_{0}$ and $z^{*}\left(-\omega^{*}\right)=$ $z^{*}\left(-\omega_{0}\right)$, we have that $\widehat{\psi}\left(\omega^{*},-z^{*}\left(-\omega^{*}\right)\right) \geq \widehat{\psi}\left(\omega_{0},-z^{*}\left(-\omega_{0}\right)\right)$. Thus, it suffices to show that $\widehat{\psi}\left(\omega_{1},-z^{*}\left(-\omega_{1}\right)\right)>\widehat{\psi}\left(\omega^{*},-z^{*}\left(-\omega^{*}\right)\right)$.

On the interval $\left(\omega^{*}, \omega_{1}\right], z^{*}(-\omega)$ is a continuously differentiable function with derivative

$$
\frac{d z^{*}(-\omega)}{d \omega}=-\frac{\mu}{2(1-\mu)}\left[\frac{H_{\eta z}\left(\frac{\mu \omega}{2(1-\mu)}+\frac{1}{2}, z^{*}(-\omega)\right)}{H_{z z}\left(\frac{\mu \omega}{2(1-\mu)}+\frac{1}{2}, z^{*}(-\omega)\right)}\right] .
$$

Accordingly, letting $\varsigma(\omega)=\widehat{\psi}\left(\omega,-z^{*}(-\omega)\right)=1-H\left(\frac{-\mu \omega}{2(1-\mu)}+\frac{1}{2},-z^{*}(-\omega)\right)$, we have that

$$
\begin{aligned}
\frac{d \varsigma}{d \omega}= & \frac{\mu}{2(1-\mu)} H_{\eta}\left(\frac{-\mu \omega}{2(1-\mu)}+\frac{1}{2},-z^{*}(-\omega)\right)+H_{z}\left(\frac{-\mu \omega}{2(1-\mu)}+\frac{1}{2},-z^{*}(-\omega)\right) \frac{d z^{*}(-\omega)}{d \omega} \\
= & \frac{\mu}{2(1-\mu)}\left\{H_{\eta}\left(\frac{-\mu \omega}{2(1-\mu)}+\frac{1}{2},-z^{*}(-\omega)\right)-\right. \\
& \left.H_{z}\left(\frac{-\mu \omega}{2(1-\mu)}+\frac{1}{2},-z^{*}(-\omega)\right)\left[\frac{H_{\eta z}\left(\frac{\mu \omega}{2(1-\mu)}+\frac{1}{2}, z^{*}(-\omega)\right)}{H_{z z}\left(\frac{\mu \omega}{2(1-\mu)}+\frac{1}{2}, z^{*}(-\omega)\right)}\right]\right\} .
\end{aligned}
$$


By symmetry, we have that $H_{\eta}\left(\frac{-\mu \omega}{2(1-\mu)}+\frac{1}{2},-z^{*}(-\omega)\right)=H_{\eta}\left(\frac{\mu \omega}{2(1-\mu)}+\frac{1}{2}, z^{*}(-\omega)\right)$ and that $H_{z}\left(\frac{-\mu \omega}{2(1-\mu)}+\frac{1}{2},-z^{*}(-\omega)\right)=H_{z}\left(\frac{\mu \omega}{2(1-\mu)}+\frac{1}{2}, z^{*}(-\omega)\right)$. Thus,

$$
\begin{aligned}
\frac{d \varsigma}{d \omega}= & \frac{\mu}{2(1-\mu)}\left\{H_{\eta}\left(\frac{\mu \omega}{2(1-\mu)}+\frac{1}{2}, z^{*}(-\omega)\right)-\right. \\
& \left.H_{z}\left(\frac{\mu \omega}{2(1-\mu)}+\frac{1}{2}, z^{*}(-\omega)\right)\left[\frac{H_{\eta z}\left(\frac{\mu \omega}{2(1-\mu)}+\frac{1}{2}, z^{*}(-\omega)\right)}{H_{z z}\left(\frac{\mu \omega}{2(1-\mu)}+\frac{1}{2}, z^{*}(-\omega)\right)}\right]\right\} .
\end{aligned}
$$

This is positive by Assumption 3, implying that $\varsigma$ is increasing on $\left(\omega^{*}, \omega_{1}\right]$. It follows that $\widehat{\psi}\left(\omega_{1},-z^{*}\left(-\omega_{1}\right)\right)>\widehat{\psi}\left(\omega^{*},-z^{*}\left(-\omega^{*}\right)\right)$ as required. QED

Proof of Proposition 4: We will show that any equilibrium of the game defined by the regulator election when the regulator is elected and the regulated firm can make campaign contributions, involves Party $A$ selecting a consumer and Party $B$ selecting a consumer if the stated inequality holds and a shareholder if the reverse inequality holds. Since a candidate's public spending preferences are irrelevant, each Party effectively has only two strategies; choosing a consumer or a shareholder. Note first that for Party $A$, the strategy $S$ is strictly dominated by the strategy $C$. It is clear that $C$ strictly dominates $S$ when Party $B$ is selecting $C$. The non-obvious case is that in which Party $B$ is choosing a shareholder. For if Party $A$ chooses a consumer, then while it is more likely to get its preferred policy outcome, it will induce costly rent seeking by the regulated firm. Party $A$ 's expected payoff from choosing a candidate of type $C$ is:

$$
\begin{aligned}
& \widehat{\psi}\left(\gamma_{C}-\gamma_{S},-z^{*}\right)\left[r\left(p^{*}(C), C\right)\right]+ \\
& {\left[1-\widehat{\psi}\left(\gamma_{C}-\gamma_{S},-z^{*}\right)\right]\left[r\left(p^{*}(S), C\right)+\frac{\lambda_{A}}{N \gamma_{S}} \pi\left(p^{*}(S)\right)\right]-\frac{\lambda_{A}}{N \gamma_{S}} z^{*}\left(\gamma_{S}-\gamma_{C}\right),}
\end{aligned}
$$

while that from choosing a type $S$ candidate is

$$
r\left(p^{*}(S), C\right)+\frac{\lambda_{A}}{N \gamma_{S}} \pi\left(p^{*}(S)\right) .
$$

Subtracting the latter from the former, the difference can be expressed as:

$$
\widehat{\psi}\left(\gamma_{C}-\gamma_{S},-z^{*}\right)\left[\Delta r(C)-\frac{\lambda_{A}}{N \gamma_{S}} \pi\left(p^{*}(S)\right)\right]-\frac{\lambda_{A}}{N \gamma_{S}} z^{*}\left(\gamma_{S}-\gamma_{C}\right) .
$$


The regulated firm's expected profits in equilibrium are

$$
\left(1-\widehat{\psi}\left(\gamma_{C}-\gamma_{S},-z^{*}\right)\right) \pi\left(p^{*}(S)\right)-z^{*}\left(\gamma_{S}-\gamma_{C}\right),
$$

and hence we have that $z^{*}\left(\gamma_{S}-\gamma_{C}\right) \leq\left(1-\widehat{\psi}\left(\gamma_{C}-\gamma_{S},-z^{*}\right)\right) \pi\left(p^{*}(S)\right)$. Thus, the difference in the payoffs from the two strategies, is at least as big as

$$
\widehat{\psi}\left(\gamma_{C}-\gamma_{S},-z^{*}\right) \Delta r(C)-\frac{\lambda_{A}}{N \gamma_{S}} \pi\left(p^{*}(S)\right) .
$$

This is positive by Assumption 4 .

Given that Party $A$ will select a consumer, Party $B$ 's payoff from selecting a consumer is given by $r\left(p^{*}(C), C\right)$, while its payoff from selecting a shareholder is

$$
\begin{aligned}
& \widehat{\psi}\left(\gamma_{C}-\gamma_{S},-z^{*}\right)\left[r\left(p^{*}(C), C\right)\right]+ \\
& {\left[1-\widehat{\psi}\left(\gamma_{C}-\gamma_{S},-z^{*}\right)\right]\left[r\left(p^{*}(S), C\right)+\frac{\lambda_{B}}{N \gamma_{S}} \pi\left(p^{*}(S)\right)\right]-\frac{\lambda_{B}}{N \gamma_{S}} z^{*}\left(\gamma_{S}-\gamma_{C}\right) .}
\end{aligned}
$$

Subtracting the latter from the former, the difference can be expressed as

$$
\left[1-\widehat{\psi}\left(\gamma_{C}-\gamma_{S},-z^{*}\right)\right]\left[\frac{\lambda_{B}}{N \gamma_{S}} \pi\left(p^{*}(S)\right)-\Delta r(C)\right]-\frac{\lambda_{B}}{N \gamma_{S}} z^{*}\left(\gamma_{S}-\gamma_{C}\right) .
$$

Thus, if the inequality stated in the proposition holds, Party $B$ selects a consumer. If the reverse inequality holds, it selects a shareholder. QED

Proof of Proposition 5: We will show that, if the stated inequality is satisfied, the equilibrium of the game defined by the gubernatorial election when the regulator is appointed and the regulated firm can make campaign contributions involves Party $A$ selecting a candidate of type $(L, S)$ and Party $B$ a candidate of type $(R, S)$. If the reverse inequality holds, the equilibrium involves Party $A$ selecting a candidate of type $(L, C)$ and Party $B$ a candidate of type $(R, S)$.

We prove the desired result via a sequence of three claims. The first of these concerns Party B's best response.

Claim 1: Selecting a candidate of type $(R, S)$ is a best response for Party $B$ when Party $A$ selects either a candidate of type $(L, C)$ or of type $(L, S)$.

Consider first the case in which Party $A$ selects a candidate of type $(L, C)$. It is obvious that $(R, S)$ yields a higher payoff for Party $B$ than $(L, C)$ so 
we focus on showing that it yields a higher payoff than $(R, C)$ or $(L, S)$. The payoff to Party $B$ from selecting $(R, S)$ is given by:

$$
\begin{aligned}
& \widehat{\psi}\left(\gamma^{L}-\gamma^{R},-z^{*}\right) W_{B}\left(g^{*}(L), p^{*}(C)\right)+ \\
& \left(1-\widehat{\psi}\left(\gamma^{L}-\gamma^{R},-z^{*}\right)\right) W_{B}\left(g^{*}(R), p^{*}(S)\right)-\frac{\lambda_{B}}{N \gamma_{S}} z^{*}\left(\gamma^{R}-\gamma^{L}\right),
\end{aligned}
$$

while the payoff from selecting $(R, C)$ is given by

$$
\psi\left(\gamma^{L}-\gamma^{R}\right) W_{B}\left(g^{*}(L), p^{*}(C)\right)+\left(1-\psi\left(\gamma^{L}-\gamma^{R}\right)\right) W_{B}\left(g^{*}(R), p^{*}(C)\right) .
$$

Subtracting the latter from the former and rearranging, yields

$$
\begin{aligned}
& \left(\psi\left(\gamma^{L}-\gamma^{R}\right)-\widehat{\psi}\left(\gamma^{L}-\gamma^{R},-z^{*}\right)\right) \Delta b(R)+ \\
& \left(1-\widehat{\psi}\left(\gamma^{L}-\gamma^{R},-z^{*}\right)\right)\left[\frac{\lambda_{B}}{N \gamma_{S}} \pi\left(p^{*}(S)\right)-\Delta r(C)\right]-\frac{\lambda_{B}}{N \gamma_{S}} z^{*}\left(\gamma^{R}-\gamma^{L}\right) .
\end{aligned}
$$

We must show that this difference is positive.

Defining the function

$$
\varsigma(z)=\left(\psi\left(\gamma^{L}-\gamma^{R}\right)-\widehat{\psi}\left(\gamma^{L}-\gamma^{R},-z\right)\right) \Delta b(R)-\frac{\lambda_{B}}{N \gamma_{S}} z,
$$

the difference may be written as

$$
\varsigma\left(z^{*}\right)+\left(1-\widehat{\psi}\left(\gamma^{L}-\gamma^{R},-z^{*}\right)\right)\left[\frac{\lambda_{B}}{N \gamma_{S}} \pi\left(p^{*}(S)\right)-\Delta r(C)\right] .
$$

Since the latter term is positive, it suffices to show that $\varsigma\left(z^{*}\right) \geq 0$. Since $\varsigma(0)=0$, we may assume that $z^{*}>0$. Observe that on the interval $\left[0, z^{*}\right]$

$$
\begin{aligned}
\varsigma^{\prime}(z) & =\frac{\partial \widehat{\psi}\left(\gamma^{L}-\gamma^{R},-z\right)}{\partial z} \Delta b(R)-\frac{\lambda_{B}}{N \gamma_{S}} \\
& =-H_{z}\left(\frac{-\mu\left(\gamma^{L}-\gamma^{R}\right)}{2(1-\mu)}+\frac{1}{2},-z\right) \Delta b(R)-\frac{\lambda_{B}}{N \gamma_{S}},
\end{aligned}
$$

and

$$
\begin{aligned}
\varsigma^{\prime \prime}(z) & =-\frac{\partial^{2} \widehat{\psi}\left(\gamma^{L}-\gamma^{R},-z\right)}{\partial z^{2}} \Delta b(R) \\
& =H_{z z}\left(\frac{-\mu\left(\gamma^{L}-\gamma^{R}\right)}{2(1-\mu)}+\frac{1}{2},-z\right) \Delta b(R)<0 .
\end{aligned}
$$


It follows that $\varsigma(z)$ is strictly concave on the interval $\left[0, z^{*}\right]$ and hence that $\varsigma\left(z^{*}\right) \geq \varsigma^{\prime}\left(z^{*}\right) z^{*}$. Thus, it suffices to show that $\varsigma^{\prime}\left(z^{*}\right) \geq 0$.

By definition

$$
z^{*}\left(\gamma^{R}-\gamma^{L}\right)=\arg \max \left\{\widehat{\psi}\left(\gamma^{R}-\gamma^{L}, z\right) \pi\left(p^{*}(S)\right)-z: z \geq 0\right\}
$$

Thus, since $z^{*}>0$,

$$
\begin{aligned}
\frac{\partial \widehat{\psi}\left(\gamma^{R}-\gamma^{L}, z^{*}\right)}{\partial z} & =-H_{z}\left(\frac{-\mu\left(\gamma^{R}-\gamma^{L}\right)}{2(1-\mu)}+\frac{1}{2}, z^{*}\right) \\
& =-H_{z}\left(\frac{-\mu\left(\gamma^{L}-\gamma^{R}\right)}{2(1-\mu)}+\frac{1}{2},-z^{*}\right)=\frac{1}{\pi\left(p^{*}(S)\right)}
\end{aligned}
$$

This means that

$$
\varsigma^{\prime}\left(z^{*}\right)=\frac{\Delta b(R)}{\pi\left(p^{*}(S)\right)}-\frac{\lambda_{B}}{N \gamma_{S}}
$$

which in turn implies that $\varsigma^{\prime}\left(z^{*}\right) \geq 0$ if $\Delta b(R) \geq \frac{\lambda_{B}}{N \gamma_{S}} \pi\left(p^{*}(S)\right)$. The latter inequality follows from the assumption that $\Delta b(R) \geq \Delta r(S)>\frac{\lambda_{B}}{N \gamma_{S}} \pi\left(p^{*}(S)\right)$.

The payoff to Party $B$ from selecting $(L, S)$ is given by:

$$
\begin{aligned}
& \widehat{\psi}\left(\gamma_{C}-\gamma_{S},-z^{*}\right) W_{B}\left(g^{*}(L), p^{*}(C)\right)+ \\
& \left(1-\widehat{\psi}\left(\gamma_{C}-\gamma_{S},-z^{*}\right)\right) W_{B}\left(g^{*}(L), p^{*}(S)\right)-\frac{\lambda_{B}}{N \gamma_{S}} z^{*}\left(\gamma_{C}-\gamma_{S}\right) .
\end{aligned}
$$

Subtracting this from the payoff from selecting $(R, S)$, we obtain

$$
\begin{aligned}
& \left(1-\widehat{\psi}\left(\gamma^{L}-\gamma^{R},-z^{*}\right)\right) \Delta b(R)+\left(\widehat{\psi}\left(\gamma_{C}-\gamma_{S},-z^{*}\right)-\widehat{\psi}\left(\gamma^{L}-\gamma^{R},-z^{*}\right)\right) \cdot \\
& {\left[\frac{\lambda_{B}}{N \gamma_{S}} \pi\left(p^{*}(S)\right)-\Delta r(C)\right]+\frac{\lambda_{B}}{N \gamma_{S}}\left(z^{*}\left(\gamma_{C}-\gamma_{S}\right)-z^{*}\left(\gamma^{R}-\gamma^{L}\right)\right) .}
\end{aligned}
$$

The fact that $\gamma_{C}-\gamma_{S}>\gamma^{L}-\gamma^{R}$, implies, by the Lemma, that $\widehat{\psi}\left(\gamma_{C}-\right.$ $\left.\gamma_{S},-z^{*}\left(\gamma_{C}-\gamma_{S}\right)\right)>\widehat{\psi}\left(\gamma^{L}-\gamma^{R},-z^{*}\left(\gamma^{R}-\gamma^{L}\right)\right)$. In addition,

$$
\begin{aligned}
\left(1-\widehat{\psi}\left(\gamma^{L}-\gamma^{R},-z^{*}\right)\right) \Delta b(R)+\frac{\lambda_{B}}{N \gamma_{S}}\left(z^{*}\left(\gamma_{C}-\gamma_{S}\right)-z^{*}\left(\gamma^{R}-\gamma^{L}\right)\right) & > \\
\varsigma\left(z^{*}\left(\gamma^{R}-\gamma^{L}\right)\right) & \geq 0
\end{aligned}
$$

These two facts imply that the difference is positive. 
Now consider the case in which Party $A$ selects a candidate of type $(L, S)$. It is obvious that $(R, S)$ yields a higher payoff for Party $B$ than $(L, C)$ or $(L, S)$, so we need only check that it yields a higher payoff than $(R, C)$. In fact, this is straightforward. Selecting a type $(R, C)$ candidate induces the lobby group to support Party $A$ 's candidate. This lowers the probability of Party $B$ achieving its preferred level of public spending and creates costly rent-seeking.

The second claim concerns Party $A$ 's best response.

Claim 2: When Party $B$ selects a candidate of type $(R, S)$, selecting a candidate of type $(L, S)$ is a best response for Party $A$ if the inequality stated in the proposition holds. If the reverse inequality holds, selecting a candidate of type $(L, C)$ is a best response.

The payoff to Party $A$ from selecting a candidate of type $(L, S)$ is given by

$$
\psi\left(\gamma^{L}-\gamma^{R}\right) W_{A}\left(g^{*}(L), p^{*}(S)\right)+\left(1-\psi\left(\gamma^{L}-\gamma^{R}\right)\right) W_{A}\left(g^{*}(R), p^{*}(S)\right),
$$

while the payoff from selecting a candidate of type $(L, C)$ is

$$
\begin{aligned}
& \widehat{\psi}\left(\gamma^{L}-\gamma^{R},-z^{*}\right) W_{A}\left(g^{*}(L), p^{*}(C)\right)+\left(1-\widehat{\psi}\left(\gamma^{L}-\gamma^{R},-z^{*}\right)\right) W_{A}\left(g^{*}(R), p^{*}(S)\right) \\
& -\frac{\lambda_{A}}{N \gamma_{S}} z^{*}\left(\gamma^{R}-\gamma^{L}\right) .
\end{aligned}
$$

Subtracting the latter from the former and rearranging, we can express the difference as

$$
\begin{aligned}
& {\left[\psi\left(\gamma^{L}-\gamma^{R}\right)-\widehat{\psi}\left(\gamma^{L}-\gamma^{R},-z^{*}\right)\right] \Delta b(L)-} \\
& \widehat{\psi}\left(\gamma^{L}-\gamma^{R},-z^{*}\right)\left[\Delta r(C)-\frac{\lambda_{A}}{N \gamma_{S}} \pi\left(p^{*}(S)\right)\right]+\frac{\lambda_{A}}{N \gamma_{S}} z^{*}\left(\gamma^{R}-\gamma^{L}\right) .
\end{aligned}
$$

If the inequality stated in the proposition is satisfied, this difference is positive so that $(L, S)$ dominates $(L, C)$. If the reverse inequality holds, $(L, C)$ dominates $(L, S)$.

To complete the proof of the Claim we need to show that if the stated inequality is satisfied, $(L, S)$ also dominates $(R, C)$ and $(R, S)$, while if the reverse inequality holds, $(L, C)$ dominates $(R, C)$ and $(R, S)$. It is clear that, irrespective of the inequality, $(L, S)$ always dominates $(R, S)$ when Party $B$ is choosing $(R, S)$. In addition, Assumption 5 implies that $(L, S)$ always dominates $(R, C)$. This immediately implies that if the stated inequality 
is satisfied, $(L, S)$ dominates $(R, C)$ and $(R, S)$. It also implies that if the reverse inequality holds, $(L, C)$ dominates $(R, C)$ and $(R, S)$ since $(L, C)$ dominates $(L, S)$ in this situation.

The previous two claims imply that, if the stated inequality is satisfied, Party $A$ selecting a candidate of type $(L, S)$ and Party $B$ a candidate of type $(R, S)$ is an equilibrium. Moreover, if the reverse inequality holds, Party $A$ selecting a candidate of type $(L, C)$ and Party $B$ a candidate of type $(R, S)$ is an equilibrium. To complete the proof we must show that there are no other equilibria. This will follow from our third and final claim.

Claim 3: In any equilibrium, Party A selects a left-wing candidate.

Let $\left\{\left(k_{A}, t_{A}\right),\left(k_{B}, t_{B}\right)\right\}$ be an equilibrium and suppose, to the converse, that $k_{A}=R$. Then there are two possibilities: (i) $k_{A}=k_{B}=R$ and (ii) $\left(k_{A}, k_{B}\right)=(R, L)$. Consider possibility (i). It must be the case that $\left(t_{A}, t_{B}\right)=$ $(C, S)$. If $\left(t_{A}, t_{B}\right)=(S, S)$, then Party $A$ could increase its payoff by choosing a type $(L, S)$ candidate; if $\left(t_{A}, t_{B}\right)=(C, C)$, then Party $A$ could increase its payoff by choosing a type $(L, C)$ candidate; and if $\left(t_{A}, t_{B}\right)=(S, C)$ then Party $A$ could increase its payoff by choosing a type $(R, C)$ candidate. Thus, Party $A$ 's payoff is given by

$$
\begin{aligned}
& \widehat{\psi}\left(\gamma_{C}-\gamma_{S},-z^{*}\right) W_{A}\left(g^{*}(R), p^{*}(C)\right)+\left(1-\widehat{\psi}\left(\gamma_{C}-\gamma_{S},-z^{*}\right)\right) W_{A}\left(g^{*}(R), p^{*}(S)\right) \\
& -\frac{\lambda_{A}}{N \gamma_{S}} z^{*}\left(\gamma_{S}-\gamma_{C}\right) .
\end{aligned}
$$

If it switches to a type $(L, S)$ candidate, its payoff is given by:

$$
\psi\left(\gamma^{L}-\gamma^{R}\right) W_{A}\left(g^{*}(L), p^{*}(S)\right)+\left(1-\psi\left(\gamma^{L}-\gamma^{R}\right)\right) W_{A}\left(g^{*}(R), p^{*}(S)\right) .
$$

Subtracting the former from the latter and rearranging, we obtain:

$$
\begin{aligned}
& \psi\left(\gamma^{L}-\gamma^{R}\right) \Delta b(L)-\widehat{\psi}\left(\gamma_{C}-\gamma_{S},-z^{*}\right)\left[\Delta r(C)-\frac{\lambda_{A}}{N \gamma_{S}} \pi\left(p^{*}(S)\right)\right] \\
& +\frac{\lambda_{A}}{N \gamma_{S}} z^{*}\left(\gamma_{S}-\gamma_{C}\right) .
\end{aligned}
$$

This is positive by Assumption 5 implying that Party $A$ benefits by deviating to a type $(L, S)$ candidate - a contradiction.

Now consider possibility (ii). It must be the case that $\left(t_{A}, t_{B}\right)=(C, S)$. If $\left(t_{A}, t_{B}\right)=(S, S)$, then Party $A$ could increase its payoff by choosing a type $(L, S)$ candidate; if $\left(t_{A}, t_{B}\right)=(C, C)$, then Party $A$ could increase its payoff 
by choosing a type $(L, C)$ candidate; and if $\left(t_{A}, t_{B}\right)=(S, C)$ then Party $A$ could increase its payoff by choosing a type $(L, C)$ candidate. Thus, Party $A$ 's payoff is given by

$$
\begin{aligned}
& \widehat{\psi}\left(\gamma^{R}-\gamma^{L},-z^{*}\right) W_{A}\left(g^{*}(R), p^{*}(C)\right)+\left(1-\widehat{\psi}\left(\gamma^{R}-\gamma^{L},-z^{*}\right)\right) W_{A}\left(g^{*}(L), p^{*}(S)\right) \\
& -\frac{\lambda_{A}}{N \gamma_{S}} z^{*}\left(\gamma^{L}-\gamma^{R}\right) .
\end{aligned}
$$

If it switches to a type $(L, S)$ candidate, its payoff is given by:

$$
W_{A}\left(g^{*}(L), p^{*}(S)\right) \text {. }
$$

Subtracting the former from the latter and rearranging, we obtain:

$\widehat{\psi}\left(\gamma^{R}-\gamma^{L},-z^{*}\right)\left\{\Delta b(L)-\left[\Delta r(C)-\frac{\lambda_{A}}{N \gamma_{S}} \pi\left(p^{*}(S)\right)\right]\right\}+\frac{\lambda_{A}}{N \gamma_{S}} z^{*}\left(\gamma_{S}-\gamma_{C}\right)>0$

Thus Party $A$ benefits by deviating to a type $(L, S)$ candidate - a contradiction.

Claim 3 implies that in any equilibrium, Party $A$ must be choosing either a type $(L, C)$ candidate or a type $(L, S)$ candidate. Claim 1 then implies that any equilibrium must involve Party $B$ selecting a type $(R, S)$ candidate. But then Claim 2 implies that any equilibrium involves Party $A$ selecting a candidate of type $(L, S)$ if the inequality stated in the proposition holds and a candidate of type $(L, C)$ if the reverse inequality holds. QED 


\subsection{Data}

I. Data for electric prices, electricity generation and fuel prices are directly collected or calculated from the EEI yearbooks.

1960-1992: Historical Statistics of the Electric Utility Industry, 1995, EEI, Washington D.C.

1993-1997: Statistical Yearbook of the Electric Utility Industry, 19931997, EEI, Washington D.C.

EEI refers to the source of data for its yearbooks to various places including U.S. Department of Energy, Energy Information Administration, Federal Power Commission and Federal Energy Regulatory Commission.

a) Electric Prices for Residential, Commercial and Industrial Sectors: EEI reports annual revenues (in dollar terms) and sales (in kilowatt-hours) of total electric utility industry by state and class of service. The prices are calculated from the revenues and sales in terms of dollars per kilowatt-hour. Besides the three sectors that are reported here, there are four other sectors categorized in the EEI yearbooks: street and highway lighting, other public authorities, railroads and railways, and interdepartmental. The three sectors take more than 95 percent of the revenues and sales throughout the years.

b) Electric Generation and Sources of Energy for Electric Generation: EEI reports two kinds of break-down of electric generation: (1) by type of prime mover driving the generator and (2) by energy source. The totals from each different break-down are consistent. We have used the second break-down here, and it consists of coal, fuel oil, gas, nuclear fuel, and hydro. There is one other source of energy that is reported to EEI is "other" which includes generation by geothermal, wood, waste, wind and solar. The generation by "other" is within 1-3 percent of total and affect only a small number of states. Generation by "hydro" was initially reported in the first category, type of prime mover, but from 1984 onwards, it was reported in both categories. Our data for "hydro" for 1960-1983 are from the first category. EEI consistently reported that for 1960-1983 the total generation in the second category is smaller than the one in the first category by the amount of "hydro". As mentioned earlier, because of the "other" the total generation is not equal to the sum of the generation by different sources in a few states. All values less than five hundred thousand kilowatt-hours are recorded as zero, as they are reported blank in EEI data.

II. Data on prices of fossil fuels reported in kilowatt hours came from the Energy Information Administration, Annual Energy Review, 1998, Table 
3.1 and denoted in dollars per British Thermal Unit (BTU) available at http://www.eia.doe.gov/emeu/aer/finance.html. To construct the fossil fuel cost index for state $i$ in year $t$, let $s_{j i t}$ be the share of energy source $j$ in state $i$ in year $t$ and let $p_{j t}$ be the price per BTU. Then the cost index $c_{i t}=\sum_{j} s_{j i t} p_{j t}$.

III. Data for commissioners are from the state yearbooks.

1960-1997: The Book of the States, 1960-1997, Council of State Governments, Lexington, KY. There are seven methods of selecting commissioners in our data. (The proportion of observations in each category are given in parentheses.)

1. Direct election $(26.13 \%)$

2. Appointed by Governor (19.12\%)

3. Appointed by Governor with confirmation by the Senate $(45.88 \%)$

4. Appointed by Governor with confirmation by executive council $(2.85 \%)$

5. Appointed by Governor with approval by legislature (2.20\%)

6. Selected by general assembly $(0.66 \%)$

7. Selected by Legislature $(3.07 \%)$

IV The data on power supply problems come from the Disturbance Analysis Working Group data base of the National Electricity Reliability Council and is available at http:/www.nerc.org for all power problems notified to the Department of Energy since 1984. They classify problems in the following categories: interruptions, voltage reductions, public appeals, load reductions and unusual occurrences. For each event, we coded which states were affected and in which year. 
Table 1: Table of Means

\begin{tabular}{|c|c|c|c|}
\hline & $\begin{array}{c}\text { States that Appoint } \\
\text { Public Utility } \\
\text { Commissioners }\end{array}$ & $\begin{array}{c}\text { States that Elect Public } \\
\text { Utility Commissioners }\end{array}$ & $\begin{array}{c}\text { States that switched } \\
\text { between } 1960 \text { and 1997 }\end{array}$ \\
\hline $\begin{array}{c}\text { Consumer price per* } \\
\text { kilowatt hour (cents) }\end{array}$ & 5.2 & 4.3 & 4.8 \\
\hline $\begin{array}{c}\text { Commercial price per } \\
\text { kilowatt hour (cents) }\end{array}$ & 4.8 & 4.2 & 4.4 \\
\hline $\begin{array}{c}\text { Industrial price per } \\
\text { kilowatt hour (cents) }\end{array}$ & 3.3 & 2.7 & 0.77 \\
\hline $\begin{array}{c}\text { Number of power } \\
\text { disturbances per year }\end{array}$ & 0.71 & 0.97 & 10033 \\
\hline $\begin{array}{c}\text { Income per capita* } \\
\text { (1982 dollars) }\end{array}$ & 10870 & 2642 & 6613 \\
\hline $\begin{array}{c}\text { State population } \\
\text { (thousands) }\end{array}$ & 4810 & 23.28 & 22.41 \\
\hline $\begin{array}{c}\text { Proportion (\%) } \\
\text { Aged 5-17 }\end{array}$ & 22.42 & 11.18 & 71.88 \\
\hline $\begin{array}{c}\text { Proportion (\%) } \\
\text { Aged 65 and over }\end{array}$ & 10.75 & 68.60 & 64.00 \\
\hline $\begin{array}{c}\text { Proportion (\%) } \\
\text { Fossil fuels }\end{array}$ & 71.77 & 72.12 & 5 \\
\hline $\begin{array}{l}\text { Proportion (\%) who } \\
\text { elect a democratic } \\
\text { governor* }\end{array}$ & 56.77 & 11 & 6.73 \\
\hline Number of states & 34 & & \\
\hline
\end{tabular}

See the data Appendix for source and definitions of variables. A ${ }^{‘} *$ ' denotes statistically significant difference between states that appoint and select at 5\% significance level. Data for Hawaii and Alaska begin in 1963. The data on power interruptions is available only for 1984-1997. 
Table 2: Mean Differences in Prices Controlling for Year Effects

\begin{tabular}{|c|c|c|c|}
\hline & $\begin{array}{c}(1) \\
\text { Residential }\end{array}$ & $\begin{array}{c}(2) \\
\text { Commercial }\end{array}$ & \begin{tabular}{c} 
Industrial \\
\hline Constant
\end{tabular} \\
& 0.999 & 0.396 & 0.81 \\
$(5.14)$ & $(2.13)$ & -0.46 \\
\hline $\begin{array}{c}\text { State elects public } \\
\text { utility commissioner }\end{array}$ & -0.770 & -0.484 & $(2.26)$ \\
\hline $\begin{array}{c}\text { Number of } \\
\text { observations }\end{array}$ & $(3.065)$ & $(2.17)$ & 50 \\
\hline $\mathrm{R}^{2}$ & 50 & 50 & 0.06 \\
\hline $\begin{array}{c}\text { Implied \% price } \\
\text { reduction in states that } \\
\text { elect their public utility } \\
\text { commissioners }\end{array}$ & -13.39 & -8.91 & -13.11 \\
\hline
\end{tabular}

See the data appendix for sources and definitions of variables. All regressions use robust standard errors. Absolute values of $\mathrm{t}$-statistics are in parentheses.

Table 3: Difference-in-difference

\begin{tabular}{|l|l|l|l|l|}
\hline \multicolumn{2}{|c|}{} & Before 1970 & $1970-1985$ & Difference \\
\hline $\begin{array}{l}\text { Residential } \\
\text { Price per kilowatt hour } \\
\text { (cents) }\end{array}$ & Appoint & 2.5 & 4.7 & 2.2 \\
\cline { 2 - 5 } & Elect & 2.2 & 3.7 & 1.5 \\
\hline $\begin{array}{l}\text { Commercial } \\
\text { Price per kilowatt hour } \\
\text { (cents) }\end{array}$ & Appoint & 2.3 & 4.5 & 2.2 \\
\cline { 2 - 5 } & Elect & 2.2 & 3.8 & 1.6 \\
\hline $\begin{array}{l}\text { Industrial } \\
\text { Price per kilowatt hour } \\
\text { (cents) }\end{array}$ & Appoint & 1.1 & 3.1 & 2.0 \\
\cline { 2 - 5 } & Elect & 1.0 & 2.6 & 1.6 \\
\hline
\end{tabular}

In each case, there is no significant difference between appointing and electing before 1970. The difference is statistically significant in the period 1970-85. 
Table 4: Basic Results

\begin{tabular}{|c|c|c|c|c|c|c|}
\hline & $\begin{array}{c}\text { (1) } \\
\text { Residential }\end{array}$ & $\begin{array}{c}\text { (2) } \\
\text { Commercial }\end{array}$ & $\begin{array}{c}\text { (3) } \\
\text { Industrial }\end{array}$ & $\begin{array}{c}\text { (4) } \\
\text { Residential }\end{array}$ & $\begin{array}{c}\text { (5) } \\
\text { Commercial }\end{array}$ & $\begin{array}{c}\text { (6) } \\
\text { Industrial }\end{array}$ \\
\hline $\begin{array}{l}\text { Elect* } \\
\text { Fossil Fuel } \\
\text { Cost }\end{array}$ & $\begin{array}{l}0.124 \\
(1.11)\end{array}$ & $\begin{array}{l}0.425 \\
(5.23)\end{array}$ & $\begin{array}{l}0.438 \\
(4.91)\end{array}$ & $\begin{array}{l}0.223 \\
(2.31)\end{array}$ & $\begin{array}{l}0.499 \\
(6.21)\end{array}$ & $\begin{array}{l}0.483 \\
(6.80)\end{array}$ \\
\hline $\begin{array}{l}\text { Appoint* } \\
\text { Fossil Fuel } \\
\text { Cost }\end{array}$ & $\begin{array}{l}0.785 \\
(10.51)\end{array}$ & $\begin{array}{l}0.839 \\
(13.01)\end{array}$ & $\begin{array}{l}0.741 \\
(10.49)\end{array}$ & $\begin{array}{l}0.615 \\
(9.14)\end{array}$ & $\begin{array}{l}0.585 \\
(8.96)\end{array}$ & $\begin{array}{l}0.734 \\
(12.37)\end{array}$ \\
\hline $\begin{array}{l}\text { F test } \\
\text { (p value) }\end{array}$ & $\begin{array}{l}57.11 \\
(0.00)\end{array}$ & $\begin{array}{l}47.26 \\
(0.00)\end{array}$ & $\begin{array}{l}18.60 \\
(0.00)\end{array}$ & $\begin{array}{l}26.08 \\
(0.00)\end{array}$ & $\begin{array}{l}1.71 \\
(0.19)\end{array}$ & $\begin{array}{l}20.41 \\
(0.00)\end{array}$ \\
\hline $\begin{array}{l}\text { State Income } \\
\text { per capita }\end{array}$ & - & - & - & $\begin{array}{l}-0.048 \\
(5.76) \\
\end{array}$ & $\begin{array}{l}-0.041 \\
(5.90) \\
\end{array}$ & $\begin{array}{l}-0.020 \\
(3.20) \\
\end{array}$ \\
\hline $\begin{array}{l}\text { State Income } \\
\text { per capita } \\
\text { squared }\end{array}$ & - & - & - & $\begin{array}{l}0.0003 \\
(10.270)\end{array}$ & $\begin{array}{l}0.0002 \\
(9.74)\end{array}$ & $\begin{array}{l}0.0002 \\
(8.91)\end{array}$ \\
\hline $\begin{array}{l}\text { State } \\
\text { population }\end{array}$ & - & - & - & $\begin{array}{l}-3.31 \mathrm{e}^{-7} \\
(7.65)\end{array}$ & $\begin{array}{l}-3.69 \mathrm{e}^{-7} \\
(8.86)\end{array}$ & $\begin{array}{l}-3.28 \mathrm{e}^{-7} \\
(10.53)\end{array}$ \\
\hline $\begin{array}{l}\text { State } \\
\text { population } \\
\text { squared }\end{array}$ & - & - & - & $\begin{array}{l}1.08 \mathrm{e}^{-14} \\
(10.71)\end{array}$ & $\begin{array}{l}1.22 \mathrm{e}^{-14} \\
(13.57)\end{array}$ & $\begin{array}{l}1.01 \mathrm{e}^{-14} \\
(14.38)\end{array}$ \\
\hline $\begin{array}{l}\text { Proportion } \\
\text { over age } 65\end{array}$ & - & - & - & $\begin{array}{l}0.131 \\
(4.377)\end{array}$ & $\begin{array}{l}0.114 \\
(4.16)\end{array}$ & $\begin{array}{l}0.099 \\
(3.80)\end{array}$ \\
\hline $\begin{array}{l}\text { Proportion } \\
5-17\end{array}$ & - & - & - & $\begin{array}{l}-0.033 \\
(1.33) \\
\end{array}$ & $\begin{array}{l}-0.0004 \\
(0.02)\end{array}$ & $\begin{array}{l}-0.048 \\
(2.12) \\
\end{array}$ \\
\hline State Effects & Yes & Yes & Yes & Yes & Yes & Yes \\
\hline Year Effects & Yes & Yes & Yes & Yes & Yes & Yes \\
\hline $\begin{array}{l}\text { Number of } \\
\text { Observations }\end{array}$ & 1769 & 1769 & 1769 & 1694 & 1694 & 1694 \\
\hline $\mathrm{R}^{2}$ & 0.98 & 0.98 & 0.99 & 0.99 & 0.98 & 0.99 \\
\hline
\end{tabular}

See the data appendix for sources and definitions of variables. All regressions use robust standard errors. Absolute values of $\mathrm{t}$-statistics are in parentheses. 
Table 5:Separate Time Periods

\begin{tabular}{|c|c|c|c|c|}
\hline & & $(1)$ & $(2)$ & (3) \\
\hline & & Residential & Commercial & Industrial \\
\hline \multirow[t]{3}{*}{$1960-69$} & $\begin{array}{l}\text { Elect } * \text { Fossil } \\
\text { Fuel Cost }\end{array}$ & $\begin{array}{l}-0.725 \\
(3.60)\end{array}$ & $\begin{array}{l}-2.11 \\
(4.73)\end{array}$ & $\begin{array}{l}-0.476 \\
(4.47)\end{array}$ \\
\hline & $\begin{array}{c}\text { Appoint } * \text { Fossil } \\
\text { Fuel Cost }\end{array}$ & $\begin{array}{l}-0.255 \\
(0.68)\end{array}$ & $\begin{array}{l}-2.38 \\
(3.81)\end{array}$ & $\begin{array}{l}-0.378 \\
(2.16)\end{array}$ \\
\hline & $\begin{array}{c}\text { F test } \\
(\mathrm{p} \text { value })\end{array}$ & $\begin{array}{c}1.90 \\
(0.17)\end{array}$ & $\begin{array}{c}0.30 \\
(0.59)\end{array}$ & $\begin{array}{c}0.39 \\
(0.53) \\
\end{array}$ \\
\hline \multirow[t]{3}{*}{$1970-85$} & $\begin{array}{c}\text { Elect } * \text { Fossil } \\
\text { Fuel Cost }\end{array}$ & $\begin{array}{l}0.528 \\
(5.54)\end{array}$ & $\begin{array}{l}0.685 \\
(8.39) \\
\end{array}$ & $\begin{array}{c}0.690 \\
(10.61)\end{array}$ \\
\hline & $\begin{array}{c}\text { Appoint } * \text { Fossil } \\
\text { Fuel Cost }\end{array}$ & $\begin{array}{c}0.958 \\
(12.55)\end{array}$ & $\begin{array}{c}0.849 \\
(11.63)\end{array}$ & $\begin{array}{c}0.879 \\
(14.10)\end{array}$ \\
\hline & $\begin{array}{c}\text { F test } \\
(\mathrm{p} \text { value })\end{array}$ & $\begin{array}{l}27.88 \\
(0.00)\end{array}$ & $\begin{array}{c}4.62 \\
(0.03) \\
\end{array}$ & $\begin{array}{l}11.08 \\
(0.00) \\
\end{array}$ \\
\hline \multirow[t]{7}{*}{$1986-97$} & $\begin{array}{c}\text { Elect } * \text { Fossil } \\
\text { Fuel Cost }\end{array}$ & $\begin{array}{l}-0.009 \\
(0.029)\end{array}$ & $\begin{array}{l}-0.449 \\
(0.59) \\
\end{array}$ & $\begin{array}{l}0.456 \\
(1.47) \\
\end{array}$ \\
\hline & $\begin{array}{c}\text { Appoint } * \text { Fossil } \\
\text { Fuel Cost }\end{array}$ & $\begin{array}{l}-0.659 \\
(1.94) \\
\end{array}$ & $\begin{array}{l}-0.252 \\
(1.54) \\
\end{array}$ & $\begin{array}{l}-0.255 \\
(0.95) \\
\end{array}$ \\
\hline & $\begin{array}{c}\text { F test } \\
(\mathrm{p} \text { value })\end{array}$ & $\begin{array}{c}2.39 \\
(0.12) \\
\end{array}$ & $\begin{array}{c}0.17 \\
(0.69) \\
\end{array}$ & $\begin{array}{c}3.33 \\
(0.07) \\
\end{array}$ \\
\hline & $\begin{array}{c}\text { Economic } \\
\text { Controls }\end{array}$ & Yes & Yes & Yes \\
\hline & State Effects & Yes & Yes & Yes \\
\hline & Year Effects & Yes & Yes & Yes \\
\hline & & & & \\
\hline
\end{tabular}

See the data appendix for sources and definitions of variables. All regressions use robust standard errors. Absolute values of $\mathrm{t}$-statistics are in parentheses. 
Table 6: Effects on Power Interruptions

\begin{tabular}{|c|c|c|c|c|c|}
\hline & (1) & (2) & (3) & (4) & (5) \\
\hline $\begin{array}{c}\text { State Elects } \\
\text { Public Utility } \\
\text { Commissioners }\end{array}$ & $\begin{array}{c}0.28 \\
(2.88)\end{array}$ & $\begin{array}{c}0.28 \\
(2.49)\end{array}$ & $\begin{array}{c}0.24 \\
(1.52)\end{array}$ & $\begin{array}{c}0.22 \\
(1.25)\end{array}$ & - \\
\hline $\begin{array}{c}\text { Elect*Past Stock } \\
\text { of Power } \\
\text { Interruptions }\end{array}$ & - & - & - & - & $\begin{array}{l}-0.15 \\
(5.66)\end{array}$ \\
\hline $\begin{array}{c}\text { Apoint*Past } \\
\text { Stock of Power } \\
\text { Interruptions }\end{array}$ & - & - & - & - & $\begin{array}{l}-0.23 \\
(8.55)\end{array}$ \\
\hline $\begin{array}{c}\text { Chi squared test } \\
\text { (p value) }\end{array}$ & - & - & - & - & $\begin{array}{l}10.02 \\
(0.00)\end{array}$ \\
\hline $\begin{array}{l}\text { Real State Income } \\
\text { per Capita }\end{array}$ & - & $\begin{array}{l}-0.002 \\
(0.15)\end{array}$ & - & $\begin{array}{l}-0.008 \\
(0.44)\end{array}$ & $\begin{array}{c}0.06 \\
(1.58)\end{array}$ \\
\hline $\begin{array}{c}\text { Real State Income } \\
\text { per Capita } \\
\text { Squared }\end{array}$ & - & $\begin{array}{l}9.17 \mathrm{e}^{-6} \\
(0.15)\end{array}$ & - & $\begin{array}{l}2.42 \mathrm{e}^{-5} \\
(0.37)\end{array}$ & $\begin{array}{c}-0.0001 \\
(1.57)\end{array}$ \\
\hline State Population & - & $\begin{array}{c}-2.78 \mathrm{e}^{-8} \\
(1.26)\end{array}$ & - & $\begin{array}{c}-2.79 \mathrm{e}^{-8} \\
(0.82)\end{array}$ & $\begin{array}{l}1.25 \mathrm{e}^{-6} \\
(2.39)\end{array}$ \\
\hline $\begin{array}{c}\text { State Population } \\
\text { Squared }\end{array}$ & - & $\begin{array}{l}1.47 \mathrm{e}^{-15} \\
(1.87)\end{array}$ & - & $\begin{array}{l}1.56 \mathrm{e}^{-15} \\
(1.30)\end{array}$ & $\begin{array}{c}-1.64 \mathrm{e}^{-14} \\
(1.79)\end{array}$ \\
\hline $\begin{array}{c}\text { Proportion over } \\
\text { age } 65\end{array}$ & - & $\begin{array}{l}-0.02 \\
(0.74) \\
\end{array}$ & - & $\begin{array}{r}-0.007 \\
(0.16) \\
\end{array}$ & $\begin{array}{c}0.41 \\
(1.67) \\
\end{array}$ \\
\hline $\begin{array}{c}\text { Proportion aged } \\
5-17\end{array}$ & - & $\begin{array}{c}0.00005 \\
(0.002)\end{array}$ & - & $\begin{array}{l}0.004 \\
(0.13) \\
\end{array}$ & $\begin{array}{l}0.030 \\
(0.53) \\
\end{array}$ \\
\hline Year Effects & Yes & Yes & Yes & Yes & Yes \\
\hline Random Effects & No & No & Yes & Yes & No \\
\hline Fixed Effects & No & No & No & No & Yes \\
\hline $\begin{array}{c}\text { Number of } \\
\text { Observations }\end{array}$ & 700 & 650 & 700 & 650 & 550 \\
\hline Pseudo $\mathrm{R}^{2}$ & 0.05 & 0.06 & - & - & 0.35 \\
\hline
\end{tabular}

See the data appendix for sources and definitions of variables. All regressions use robust standard errors. Absolute values of z-statistics are in parentheses. 
Appendix Table 1: Basic Results Removing the States that Switched

\begin{tabular}{|c|c|c|c|c|c|c|}
\hline & $\begin{array}{c}\text { (1) } \\
\text { Residential }\end{array}$ & $\begin{array}{c}\text { (2) } \\
\text { Commercial } \\
\end{array}$ & $\begin{array}{c}\text { (3) } \\
\text { Industrial }\end{array}$ & $\begin{array}{c}\text { (4) } \\
\text { Residential }\end{array}$ & $\begin{array}{c}\text { (5) } \\
\text { Commercial }\end{array}$ & $\begin{array}{c}\text { (6) } \\
\text { Industrial }\end{array}$ \\
\hline $\begin{array}{l}\text { Elect* } \\
\text { Fossil Fuel } \\
\text { Cost }\end{array}$ & $\begin{array}{l}-0.170 \\
(1.61)\end{array}$ & $\begin{array}{l}0.163 \\
(1.97)\end{array}$ & $\begin{array}{l}0.118 \\
(1.29)\end{array}$ & $\begin{array}{l}0.112 \\
(1.16)\end{array}$ & $\begin{array}{l}0.329 \\
(3.62)\end{array}$ & $\begin{array}{l}0.336 \\
(4.51)\end{array}$ \\
\hline $\begin{array}{l}\text { Appoint* } \\
\text { Fossil Fuel } \\
\text { Cost }\end{array}$ & $\begin{array}{l}0.805 \\
(10.50)\end{array}$ & $\begin{array}{l}0.861 \\
(13.04)\end{array}$ & $\begin{array}{l}0.756 \\
(10.39)\end{array}$ & $\begin{array}{l}0.631 \\
(8.78)\end{array}$ & $\begin{array}{l}0.610 \\
(8.73)\end{array}$ & $\begin{array}{l}0.760 \\
(12.01)\end{array}$ \\
\hline $\begin{array}{l}\text { F test } \\
\text { (p value) }\end{array}$ & $\begin{array}{l}142.16 \\
(0.00)\end{array}$ & $\begin{array}{l}126.15 \\
(0.00)\end{array}$ & $\begin{array}{c}74.96 \\
(0.00)\end{array}$ & $\begin{array}{l}42.99 \\
(0.00)\end{array}$ & $\begin{array}{l}12.91 \\
(0.00)\end{array}$ & $\begin{array}{l}48.14 \\
(0.00)\end{array}$ \\
\hline $\begin{array}{l}\text { State Income } \\
\text { per capita }\end{array}$ & - & - & - & $\begin{array}{l}-0.048 \\
(5.46)\end{array}$ & $\begin{array}{l}-0.039 \\
(5.23)\end{array}$ & $\begin{array}{l}-0.017 \\
(2.55)\end{array}$ \\
\hline $\begin{array}{l}\text { State Income } \\
\text { per capita } \\
\text { squared }\end{array}$ & - & - & - & $\begin{array}{l}0.0003 \\
(9.71)\end{array}$ & $\begin{array}{l}0.0002 \\
(8.70)\end{array}$ & $\begin{array}{l}0.0002 \\
(7.88)\end{array}$ \\
\hline $\begin{array}{l}\text { State } \\
\text { population }\end{array}$ & - & - & - & $\begin{array}{l}-3.15 \mathrm{e}^{-7} \\
(3.41)\end{array}$ & $\begin{array}{l}-2.42 \mathrm{e}^{-7} \\
(2.69)\end{array}$ & $\begin{array}{l}-2.78 \mathrm{e}^{-7} \\
(4.11)\end{array}$ \\
\hline $\begin{array}{l}\text { State } \\
\text { population } \\
\text { squared }\end{array}$ & - & - & - & $\begin{array}{l}1.05 \mathrm{e}^{-14} \\
(5.87)\end{array}$ & $\begin{array}{l}9.80 \mathrm{e}^{-15} \\
(5.66)\end{array}$ & $\begin{array}{l}9.24 \mathrm{e}^{-15} \\
(7.02)\end{array}$ \\
\hline $\begin{array}{l}\text { Proportion } \\
\text { over age } 65\end{array}$ & - & - & - & $\begin{array}{l}0.096 \\
(2.65)\end{array}$ & $\begin{array}{l}0.096 \\
(2.96)\end{array}$ & $\begin{array}{l}0.069 \\
(2.22)\end{array}$ \\
\hline $\begin{array}{l}\text { Proportion } \\
5-17\end{array}$ & - & - & - & $\begin{array}{l}-0.032 \\
(1.25) \\
\end{array}$ & $\begin{array}{l}-0.002 \\
(0.08)\end{array}$ & $\begin{array}{l}-0.051 \\
(2.19) \\
\end{array}$ \\
\hline State Effects & Yes & Yes & Yes & Yes & Yes & Yes \\
\hline Year Effects & Yes & Yes & Yes & Yes & Yes & Yes \\
\hline $\begin{array}{l}\text { Number of } \\
\text { Observations }\end{array}$ & 1589 & 1589 & 1589 & 1519 & 1519 & 1519 \\
\hline $\mathrm{R}^{2}$ & 0.98 & 0.98 & 0.99 & 0.99 & 0.98 & 0.99 \\
\hline
\end{tabular}




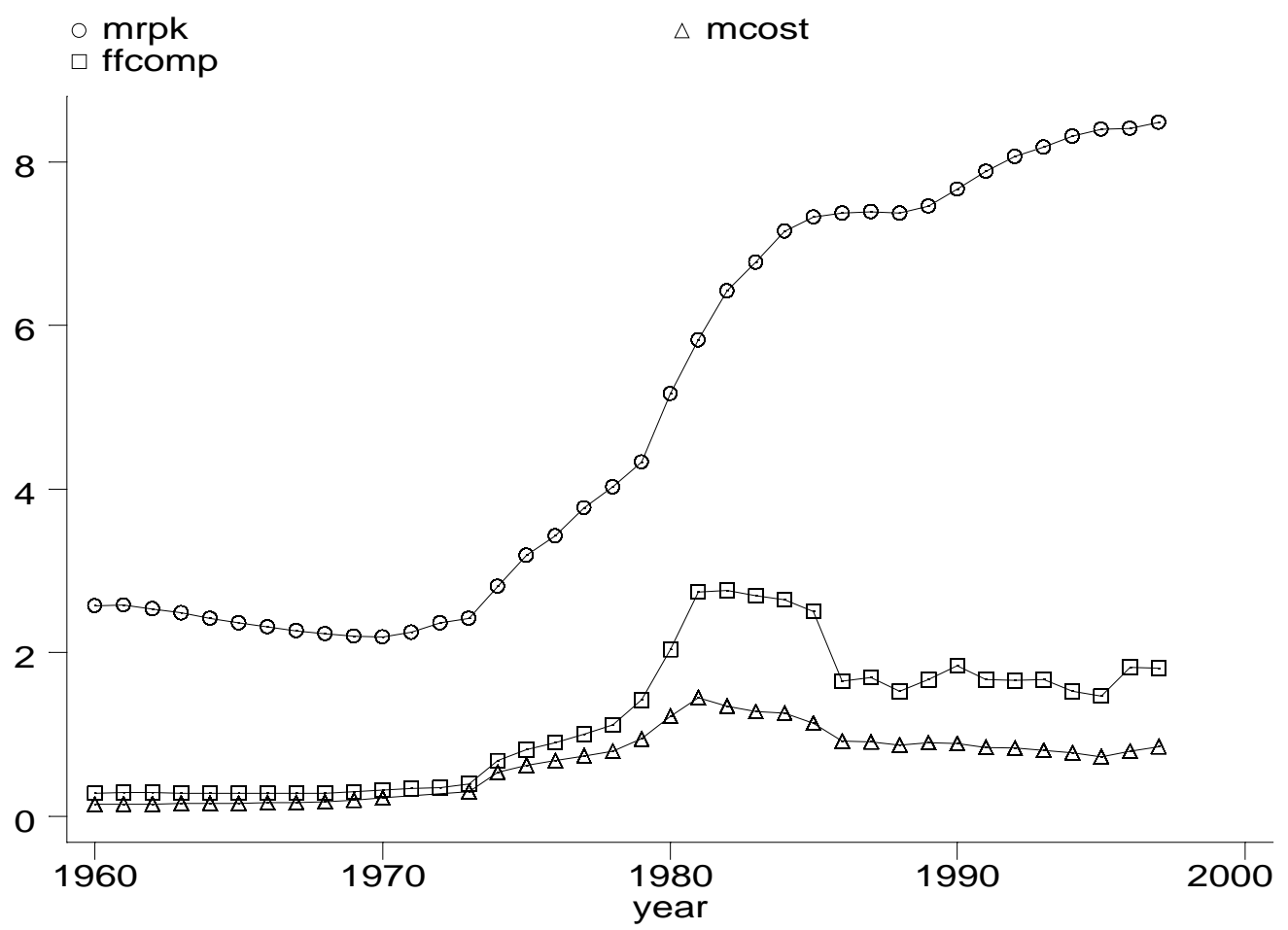

Figure 1: 


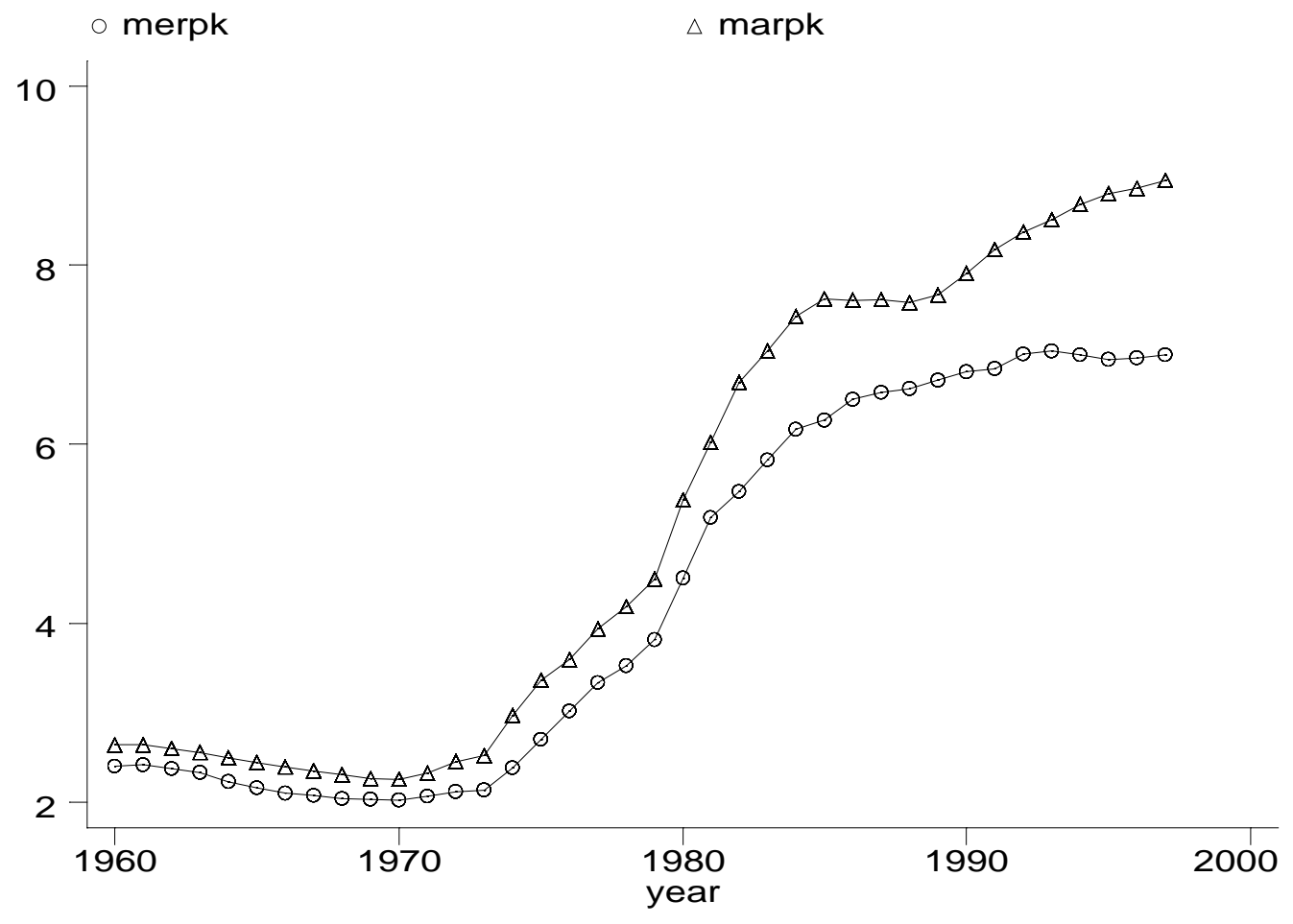

Figure 2: Mean Residential Prices over Time 


\section{Appendix Table 2}

List of States

\begin{tabular}{|l|l|}
\hline Elect: & AL, AZ, GA, LA, MS, MT, ND, NE, OK, SD, TN \\
\hline Appoint: & AK, AR, CA, CO, CT, DE, HI, ID IL, IN, KS, KY, \\
& MA, MD, ME, MI, MO, NC, NH, NJ, NM, NV, \\
& NY, OH, OR, PA, RI, VT, WA, WI, WY, WV \\
\hline Switch: & FL, IA, MN, SC, TX \\
\hline
\end{tabular}

Note: - Florida switched from elect to appoint in 1981

- Iowa switched to an election system for $1962 \& 3$ only

- Minnesota used election 1960-71, appointing 1972-5 and electing from 1976-77 and appointment since 1978

- $\quad$ South Carolina switched to an election system in 1996

- Texas switched to an appointment system in 1977 